University of Nebraska - Lincoln

DigitalCommons@University of Nebraska - Lincoln

Agronomy \& Horticulture -- Faculty Publications

Agronomy and Horticulture Department

7-1924

\title{
Plant Production as a Measure of Environment: A Study in Crop Ecology
}

J. E. Weaver

University of Nebraska-Lincoln

Follow this and additional works at: https://digitalcommons.unl.edu/agronomyfacpub

Part of the Plant Sciences Commons

Weaver, J. E., "Plant Production as a Measure of Environment: A Study in Crop Ecology" (1924). Agronomy \& Horticulture -- Faculty Publications. 506.

https://digitalcommons.unl.edu/agronomyfacpub/506

This Article is brought to you for free and open access by the Agronomy and Horticulture Department at DigitalCommons@University of Nebraska - Lincoln. It has been accepted for inclusion in Agronomy \& Horticulture -Faculty Publications by an authorized administrator of DigitalCommons@University of Nebraska - Lincoln. 


\title{
PLANT PRODUCTION AS A MEASURE OF ENVIRONMENT
}

\author{
A STUDY IN CROP ECOLOGY
}

By J. E. WEAVER, University of Nebraska.

(With Plates I-V and fourteen Figures in the Text.)

\begin{tabular}{|c|c|c|c|}
\hline \multicolumn{4}{|c|}{ CONTENTS. } \\
\hline INTRODUCTION & • & . & .205 \\
\hline Location and Description of & Stations & . & . 206 \\
\hline COMPARISON OF ENVIRONMENTS & 5 & . & 212 \\
\hline Experimental Methods and & Results, & 1920 & . 217 \\
\hline EXPERIMENTS DURING 1921 & . & . & 222 \\
\hline Environmental conditions & . & . & . 222 \\
\hline Plant yield & . & & . 227 \\
\hline EXPERIMENTS DURING 1922 & . & & . 230 \\
\hline Environmental conditions & . & . & 230 \\
\hline Native plant yield & . & & 232 \\
\hline Growth of maize & e & & . 234 \\
\hline Summary of experiments 0 & native $\mathrm{v}$ & & n 236 \\
\hline SUMmary . & . & 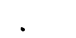 & 236 \\
\hline
\end{tabular}

\section{INTRODUCTION.}

The most fundamental relation in plant ecology is that reciprocal one between the plant and its habitat. Any attempt to determine exactly the causes which are producing modifications in the individual, and consequently in vegetation, must include careful measurements of all of the habitat factors. This must be done with instruments of precision in order to determine the exact amount of each factor that is present in the habitat. It forms a basis for determining the ratio between the stimulus and the amount of functional and structural adjustment that results. However, a fundamental and apparently inevitable objection to all instruments is their failure to express factor differences in terms of plant activities. Moreover, while instruments record the individual factors, most of them fail to integrate the factors concerned. This is a serious drawback, since measurements of functions are regularly obtained as sums. Even with a complete set of habitat factors the interpretation is difficult, for the final decision as to the amount or intensity of any factor necessary to produce a functional or structural response can be determined only by the plant. Thus while factor intensities must be measured by 
instruments, effects that produce changes in vegetation must be determined by the living organism, the plant.

The investigations here reported in part only were made in*an attempt to analyse the intricate relations between plant and habitat with the hope of determining more exactly the effect of varying amounts of factors upon plant response. Individual plant responses such as transpiration, photosynthesis, etc., are not recorded here ${ }^{1}$ but rather the integration and summation of these responses as determined by growth of both native and cultivated plants. It was discovered early in these investigations that the water relations of soil and air were the controlling factors, all others being of secondary importance. The critical nature of this one factor-complex permits of a clear correlation between plant production and environment.

\section{LOCATION AND DESCRIPTION OF STATIONS.}

In the beginning of this study, stations were carefully chosen to represent typical conditions in each of the three climax grassland communities occurring in the vast area between the Missouri River and the Rocky Mountains.

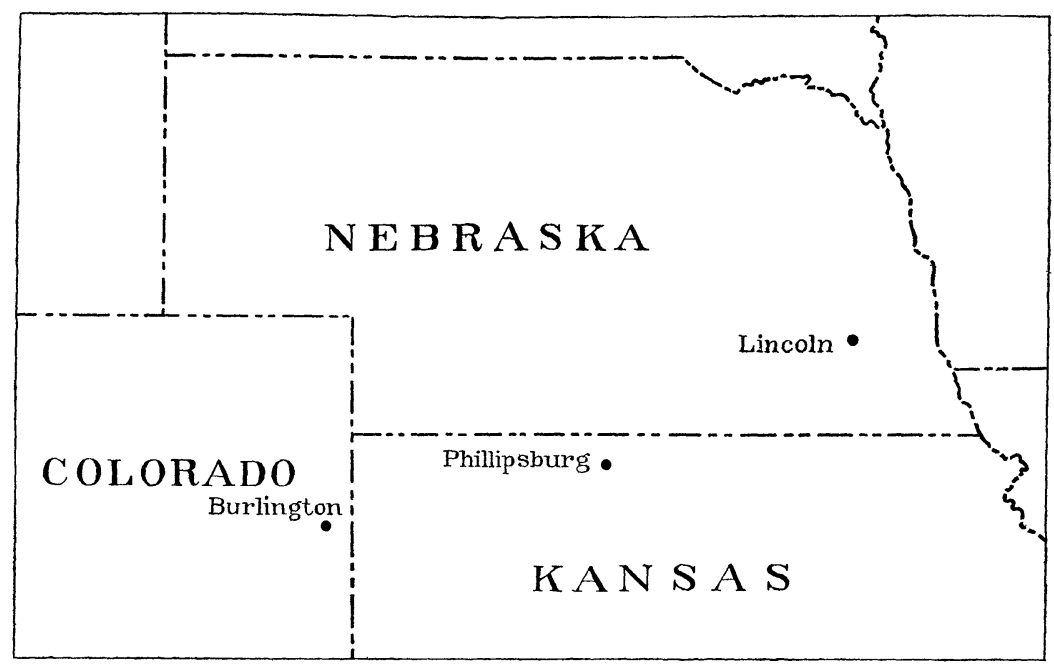

Fic. 1. Map showing location of the stations in true prairie (Lincoln), mixed prairie (Phillipsburg), and short-grass plains (Burlington).

Lincoln, in eastern Nebraska, was selected as representative of true prairie conditions, Phillipsburg, in north-central Kansas of mixed prairie, while Burlington, in eastern Colorado, was chosen in the short-grass plains. Phillipsburg lies about 190 miles south-west of Lincoln, and Burlington, 10 miles west

1 A comprehensive statement of the effects of environment, at the several stations here described, on the responses of individual native and crop plants is now in press. These include data from investigations extending throughout a period of four years, on germination, establishment, rate of growth of root and shoot, reproduction, transpiration, water requirement, etc. (Cf. Glements and Weaver, 1922). 
of the Kansas-Colorado state line, about 180 miles further west and south (Fig. 1). The altitude at the several stations varies from 1100 feet at Lincoln to 1900 at Phillipsburg and 4160 feet at Burlington. Precipitation, the chief factor in determining the type of vegetation, varies from 28 to 23 and 17 inches at the several stations respectively, decreasing westward.

Two stations at which factors were measured were maintained at Lincoln. One was located on the high prairie on a rather flat hill top about 60 feet above the general level of the flood plain of Salt Creek and about two miles north of the city. The fertile soil is of the type commonly called loess, but it is much confounded with glacial drift. It is a silt-loam belonging to the Marshall series with a moisture equivalent of about 30 per cent. and a maximum water-capacity of 60 to 70 per cent. The low prairie station was located on a level tract at the foot of the hill only a quarter of a mile southward. The soil is a fertile dark-coloured silt loam of the Wabash series. Mechanical and chemical analyses taken from cropped plats adjacent to the two grassland areas respectively represent fairly well their salient characteristics. An examination of Table 1 shows that both soils are fine textured, being composed mostly of silt and clay.

TABLE 1. Mechanical analyses of soils from Lincoln.

\begin{tabular}{|c|c|c|c|c|c|c|c|c|c|}
\hline $\begin{array}{l}\text { Depth of } \\
\text { sample }\end{array}$ & $\begin{array}{l}\text { Coarse } \\
\text { gravel }\end{array}$ & $\begin{array}{l}\text { Fine } \\
\text { gravel }\end{array}$ & $\begin{array}{l}\text { Coarse } \\
\text { sand }\end{array}$ & $\begin{array}{l}\text { Medium } \\
\text { sand }\end{array}$ & $\begin{array}{l}\text { Fine } \\
\text { sand }\end{array}$ & $\begin{array}{l}\text { Very fine } \\
\text { sand }\end{array}$ & Silt & Clay & $\begin{array}{l}\text { Moisture } \\
\text { equivalent }\end{array}$ \\
\hline Upland plats: & $\%$ & $\%$ & $\%$ & $\%$ & $\%$ & $\%$ & $\%$ & $\%$ & $\%$ \\
\hline $0.0-0.5 \mathrm{ft}$. & $0 \cdot 0$ & $0 \cdot 0$ & $0 \cdot 3$ & 0.5 & $1 \cdot 6$ & $19 \cdot 8$ & $48 \cdot 6$ & $29 \cdot 2$ & $31 \cdot 4$ \\
\hline $0 \cdot 5-1.0 \mathrm{ft}$. & $0 \cdot 0$ & $0 \cdot 0$ & $0 \cdot 2$ & $0 \cdot 6$ & $1 \cdot 3$ & $16 \cdot 7$ & $52 \cdot 4$ & $28 \cdot 8$ & $31 \cdot 8$ \\
\hline $1-2 \mathrm{ft}$ & $0 \cdot 0$ & $0 \cdot 0$ & $0 \cdot \overline{1}$ & $0 \cdot 2$ & $0 \cdot 8$ & $16 \cdot 7$ & $55 \cdot 6$ & $26 \cdot 6$ & $31 \cdot 5$ \\
\hline $2-3 \mathrm{ft}$. & $0 \cdot 0$ & $0 \cdot 0$ & $0 \cdot 1$ & $0 \cdot 1$ & 0.5 & $19 \cdot 0$ & $57 \cdot 9$ & $22 \cdot 3$ & $30 \cdot 1$ \\
\hline \multicolumn{10}{|l|}{ Lowland plats: } \\
\hline $0 \cdot 0-0$ & $0 \cdot 1$ & 0.4 & $2 \cdot 2$ & $1 \cdot 8$ & $5 \cdot 0$ & $25 \cdot 0$ & $41 \cdot 3$ & $24 \cdot 3$ & $27 \cdot 7$ \\
\hline $0 \cdot 5-1 \cdot($ & 0 & $0 \cdot 7$ & $2 \cdot 1$ & $2 \cdot$ & 5 . & & $38 \cdot 8$ & 25 . & $27 \cdot 9$ \\
\hline $1-2 \mathrm{ft}$. & $0 \cdot 2$ & $0 \cdot 3$ & $1 \cdot 3$ & 1.5 & $3 \cdot 7$ & $21 \cdot 4$ & $40 \cdot 8$ & $31 \cdot 0$ & $30 \cdot 6$ \\
\hline $2-3 \mathrm{ft}$. & $0 \cdot 0$ & $0 \cdot 1$ & $0 \cdot 4$ & 0.5 & 1.7 & $19 \cdot 2$ & $43 \cdot 4$ & $34 \cdot 7$ & $32 \cdot 9$ \\
\hline
\end{tabular}

Table 2 gives the chemical composition of representative composite samples of soil at the various depths from the two areas. These data show that the soils at the two stations are not strikingly different. It may be noted that the lime content is about the same in both fields. Both soils (which had been cropped for many years) showed medium acidity in the first foot, slight in the second, very slight in the third, while the fourth foot gave no acidity but was slightly carbonaceous. However, in the grassland the soils were free from acid at both stations and at all depths.

Owing to the higher humus content of the lowland soils, coupled with a more abundant water supply, the yield of both native and cultivated crops was much greater than on the upland.

Water-content determinations throughout a long series of years show that the subsoil of the high prairie is usually moist to great depths, although at 
TABLE 2. Chemical analyses of soils from Lincoln by digestion with hydrochloric acid (sp. gr. 1·115) for 120 hours.

\begin{tabular}{|c|c|c|c|c|c|c|c|c|}
\hline Depth of sample & $\begin{array}{l}\text { Insoluble } \\
\text { residue }\end{array}$ & $\begin{array}{l}\text { Soluble } \\
\text { salts }\end{array}$ & $\begin{array}{c}\text { Volatile } \\
\text { matter }\end{array}$ & $\begin{array}{c}\text { Iron and } \\
\text { aluminium } \\
\text { oxides }\end{array}$ & $\begin{array}{c}\text { Calcium } \\
\text { oxide }\end{array}$ & $\begin{array}{l}\text { Magne- } \\
\text { sium } \\
\text { oxide }\end{array}$ & $\begin{array}{c}\text { Phos- } \\
\text { phorus } \\
\text { pentoxide }\end{array}$ & Nitrogen \\
\hline Upland plats: & $\%$ & $\%$ & $\%$ & $\%$ & $\%$ & $\%$ & $\%$ & $\%$ \\
\hline $0.0-0.5 \mathrm{ft}$. & $76 \cdot 87$ & $17 \cdot 12$ & $6 \cdot 01$ & $13 \cdot 20$ & $0 \cdot 68$ & $1 \cdot 19$ & $0 \cdot 13$ & $0 \cdot 159$ \\
\hline $0 \cdot 5-1 \cdot 0$ & $75 \cdot 70$ & $18 \cdot 58$ & $5 \cdot 72$ & $14 \cdot 25$ & $0 \cdot 70$ & $1 \cdot 32$ & $0 \cdot 12$ & $0 \cdot 134$ \\
\hline $1-2$ & $76 \cdot 17$ & $19 \cdot 08$ & $4 \cdot 75$ & $14 \cdot 72$ & 0.75 & $1 \cdot 68$ & $0 \cdot 12$ & $0 \cdot 079$ \\
\hline $2-3$ & $77 \cdot 86$ & $18 \cdot 46$ & $3 \cdot 68$ & $14 \cdot 03$ & 0.86 & $1 \cdot 69$ & $0 \cdot 15$ & $0 \cdot 045$ \\
\hline \multicolumn{9}{|l|}{ Lowland plats: } \\
\hline $0.0-0.5 \mathrm{ft}$. & $79 \cdot 34$ & $12 \cdot 96$ & $7 \cdot 70$ & $9 \cdot 57$ & $0 \cdot 68$ & $0 \cdot 75$ & $0 \cdot 13$ & $0 \cdot 218$ \\
\hline $0 \cdot 5-1 \cdot 0$ & $79 \cdot 63$ & $13 \cdot 66$ & $6 \cdot 71$ & $10 \cdot 27$ & $0 \cdot 63$ & $0 \cdot 77$ & $0 \cdot 10$ & $0 \cdot 187$ \\
\hline $1-2$ & $78 \cdot 11$ & $15 \cdot 83$ & $6 \cdot 06$ & $12 \cdot 11$ & $0 \cdot 64$ & 1.01 & $0 \cdot 08$ & $0 \cdot 135$ \\
\hline $2-3$ & $74 \cdot 78$ & $19 \cdot 82$ & $5 \cdot 40$ & $15 \cdot 20$ & $0 \cdot 76$ & $1 \cdot 27$ & 0.09 & $0 \cdot 082$ \\
\hline
\end{tabular}

infrequent intervals during drought periods the holard may be reduced below the wilting coefficient of Briggs and Shantz (1912) to depths of 4 or 5 feet, leaving only a small chresard for vegetation (cf. Weaver. 1920, 28). Root excavations and bisects show that the plants are not only rooted deeply, but that the root-systems of different species form layers in the soil, the shallowest one ending at about two feet, an intermediate one at five feet, while a third layer extends far below this level (loc. cit. 40).

The vegetation is distinctly of the tall-grass sod type. Andropogon scoparius, Stipa spartea, Koeleria cristata, Bouteloua racemosa and Andropogon nutans are the chief grasses, although Andropogon furcatus occurs sparingly with Poa pratensis. The interstitial Panicum scribnerianum, and Bouteloua gracilis are of much less importance. Prevernal societies are represented by Antennaria campestris and Carex pennsylvanica. Such vernal bloomers as Astragalus crassicarpus, Baptisia bracteata, Senecio plattensis and Nothocalais cuspidata are abundant, while the variety and abundance of estival herbs indicate favourable growth conditions throughout the early summer. Chief among these are Psoralea floribunda, Erigeron ramosus, Brauneria pallida, Meriolix serrulata, and Achillea millefolium, although a host of others occur (Weaver and Thiel, 1917). Many species of Solidago, Aster, Liatris, Helianthus, Kuhnia, etc., constitute the major part of the autumnal societies. Thus, the vegetation at the true prairie station is kaleidoscopic in seasonal appearance. An average height level of grasses of 6 inches and an upper story of herbs at 15 to 22 inches occurs by June 1, although the flower stalks of Stipa and later blooming grasses and herbs are 2.5 to 3.5 feet tall (Pl. I $a$ ).

The low prairie area is dominated by a few species less xerophytic than those occurring on the high prairie. Many of the species of high prairie are absent, but are replaced in part by others of a more mesophytic kind. 'The dominant grasses are Andropogon furcatus, Panicum virgatum, Andropogon nutans and Spartina cynosuroides, each of which often covers small areas with a pure or nearly pure growth. Poa pratensis is also very important, but is exceeded by the taller grasses which reach a height of 5 or 6 feet (Pl. I $b$ ). 

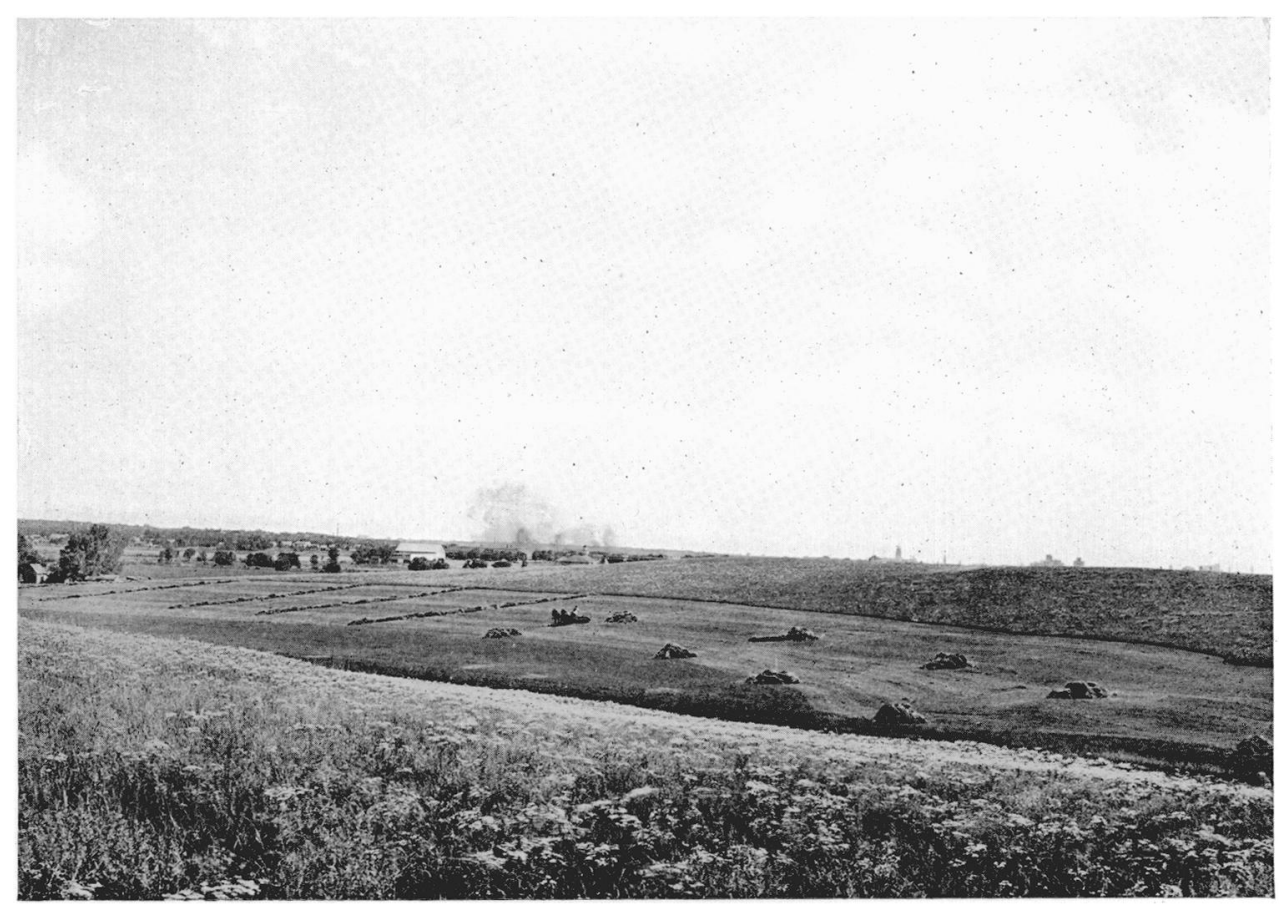

(a) High prairie near Lincoln, Nebraska, showing the continuous tall-grass cover, the abundance of societies and the amount of hay produced. Photographed June 25, 1920.

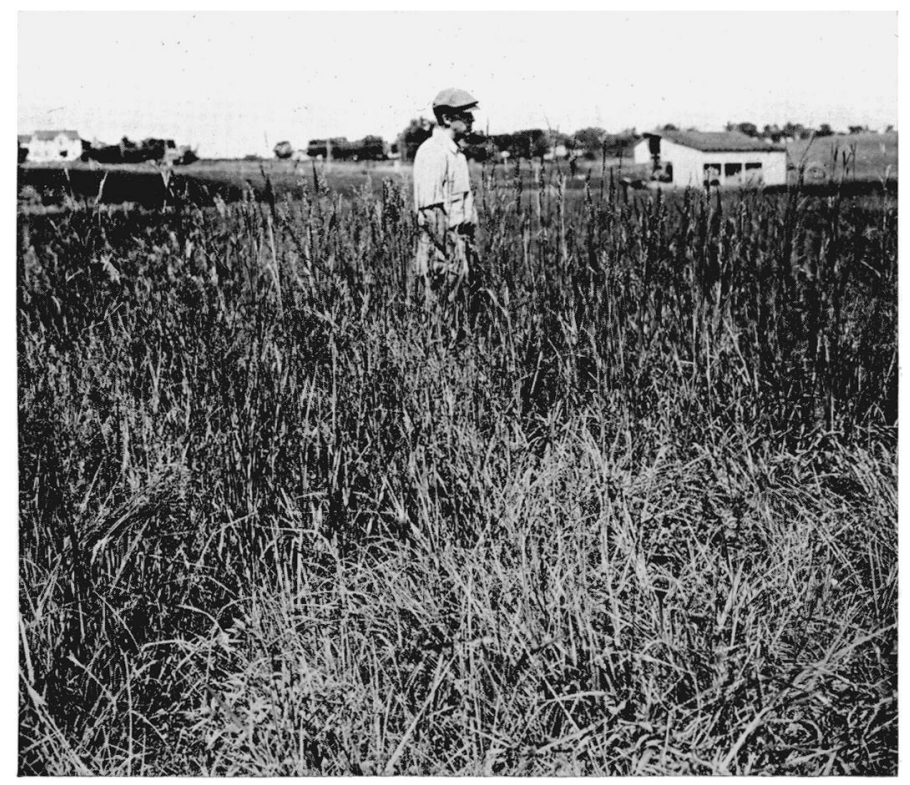

(b) Low prairie near Lincoln. Detailed view showing the density and height of Andropogon furcatus, A. nutans and P'anium virgatum. Photographed August 30, 1922. 
Characteristic herbs are Solidago canadensis, S. missouriensis, S. rigida, Glycyrrhiza lepidota, Aster multiflorus, A. salicifolius, Physalis heterophylla, Polygonum muhlenbergii, Artemisia gnaphalodes, Achillea millefolium, and Callirrhoe alceoides. The rank growth forms a dense cover and makes ecesis in the area very difficult.

Bisects show that the plants are rooted deeply, in fact most reach depths of 5 to 12 feet. Root-layers at 3 and 5 feet are quite as distinct as those on the high prairie.

The mixed prairie station occupies an area just south of Phillipsburg, quite typical of the gently rolling topography, on a hillside which slopes southward. The fertile soil is a mellow dark-brown very fine-sandy loam of the Colby series. At a depth of 12 to 15 inches it is slightly lighter in colour and contains enough clay to be quite sticky, although when wet it is dark in colour to a depth of two feet. Below this level it is light yellow, and shows throughout its loess origin. The first four feet have a water-holding capacity of about 66 per cent. As is true of most soils of semiarid regions, it shows no acidity at any depth. The mellow subsoil is very deep. Repeated excavations

TABLE 2a. Mechanical analyses of soils from Phillipsburg.

$\begin{array}{ccccccccc}\begin{array}{c}\text { Depth, } \\ \text { feet }\end{array} & \begin{array}{c}\text { Coarse } \\ \text { gravel }\end{array} & \begin{array}{c}\text { Fine } \\ \text { gravel }\end{array} & \begin{array}{c}\text { Coarse } \\ \text { sand }\end{array} & \begin{array}{c}\text { Medium } \\ \text { sand }\end{array} & \begin{array}{c}\text { Fine } \\ \text { sand }\end{array} & \begin{array}{c}\text { Very fine } \\ \text { sand }\end{array} & \text { Silt } & \text { Clay } \\ 0 \cdot 0-0 \cdot 5 & 0 \cdot 0 & 0 \cdot 0 & 0 \cdot 3 & 0 \cdot 2 & 1 \cdot 2 & 43 \cdot 5 & 35 \cdot 8 & 19 \cdot 0 \\ 0 \cdot 5-1 \cdot 0 & 0 \cdot 0 & 0 \cdot 0 & 0 \cdot 0 & 0 \cdot 2 & 0 \cdot 5 & 44 \cdot 4 & 32 \cdot 8 & 22 \cdot 1 \\ 1-2 & 0 \cdot 0 & 0 \cdot 0 & 0 \cdot 0 & 0 \cdot 2 & 0 \cdot 3 & 39 \cdot 7 & 34 \cdot 0 & 25 \cdot 8 \\ 2-3 & 0 \cdot 0 & 0 \cdot 0 & 0 \cdot 0 & 0 \cdot 3 & 0 \cdot 6 & 41 \cdot 2 & 31 \cdot 9 & 26 \cdot 0 \\ 3-4 & 0 \cdot 0 & 0 \cdot 0 & 0 \cdot 0 & 0 \cdot 1 & 0 \cdot 2 & 37 \cdot 5 & 31 \cdot 4 & 30 \cdot 8\end{array}$

for the examination of the roots of both native and crop plants during 1919 to 1921 showed that it was quite moist at least to 8 feet, a condition which is thought to be rather abnormal for the region, but one which can be directly correlated with the 11 inches excess precipitation of 1919 (cf. Weaver, Jean and Crist, 1922, 77). However, this station is somewhat subject to drought, the holard even to a depth of 4 feet being sometimes reduced to approximately the hygroscopic coefficient, about $10 \cdot 6$ per cent. Under these conditions the native vegetation is rooted almost or quite as deeply as in the true prairie (Weaver, 1920, 93). The vegetation is typical mixed prairie, the tall-grasses alternating with or forming a layer above the shorter ones (Pl. II a). Andropogon scoparius, $A$. nutans and $A$. furcatus often form more or less continuous irregular sodded areas varying from. 6 inches to 7 feet in diameter where shortgrasses may be almost entirely excluded, while Agropyrum glaucum frequently occupies large areas rather exclusively. Bouteloua racemosa and Elymus canadensis are other important tall-grasses. Alternating with these are similar or, on drier slopes, even larger areas of Bulbilis dactyloides and Bouteloua gracilis, intervening areas often to the extent of one-fourth of the surface being nearly devoid of vegetation. Perhaps more usually, however, the shortand tall-grasses are intimately mixed, the latter often showing strong ten- 
dencies towards the bunch habit. Carex filifolia and C. stenophylla supplement the understory of grasses which reaches an average height of about 4 inches (before flower-stalk production) as contrasted with the mid-summer tall-grass level 4 to 10 inches above. An overtopping, more or less discontinuous layer of Psoralea tenuiflora at 2 feet characterizes much of the area in late June, when societies of Ratibida columnaris and Morongia uncinata are also conspicuous. However, as emphasized by Clements $(1920,138)$ the mixed prairies show their xerophytism by less numerous and less extensive groups of non-grassy herbs. Antennaria campestris, Astragalus crassicarpus, Nothocalais cuspidata, Anemone caroliniana, Senecio plattensis, Vicia americana, etc., are all represented, even if sparingly, in the spring and early summer, the absence of Viola, Stipa, Koeleria and Brauneria is at once noted, while the presence of Astragalus mollissimus, Oxytropis lamberti, Malvastrum coccineum, Opuntia fragilis, O. camanchica, Aristida purpurea and Plantago purshii indicates a more xerophytic type of vegetation. The Erigerons, Meriolix, etc., of mid-summer are usually smaller and less abundant than eastward, while the autumnal aspect likewise lacks many species common to the true prairies.

The plains station is located just north of Burlington on a vast level tract. The soil is a rich, brown, fine-sandy loam, very compact and hard when dry. It has a water-holding capacity of 65 to 70 per cent. to a depth of 4 feet. At a depth of 2 to 2.5 feet it is underlaid with a so-called hardpan. Soil analyses show that the concentration of colloidal clay and carbonates in the subsoil is sufficient to give rise to a hardpan, i.e. a much more compact stratum of soil relative to that above or below it, upon its becoming completely dried out (Weaver and Crist, 1922). An examination of Table 3 shows that silt constitutes about one-third of the soil at all depths, while the sand decreases and the clay increases in amount to 4 feet.

TABLE 3. Mechanical analyses of soils from Burlington, Colorado.

Depth of sample in feet

$\begin{array}{lcccccc} & & \begin{array}{c}0 \cdot 0-0.5 \\ \%\end{array} & \begin{array}{c}0 \cdot 5-1 \cdot 0 \\ \%\end{array} & \begin{array}{c}1-2 \\ \%\end{array} & \begin{array}{c}2-3 \\ \%\end{array} & 3-4 \\ \text { Coarse gravel } & \ldots & 0 \cdot 0 & 0 \cdot 0 & 0 \cdot 0 & 0 \cdot 0 & 0 \cdot 0 \\ \text { Fine gravel } & \ldots & 0 \cdot 0 & 0 \cdot 0 & 0 \cdot 0 & 0 \cdot 0 & 0 \cdot 0 \\ \text { Coarse sand } & \ldots & 0 \cdot 0 & 0 \cdot 0 & 0 \cdot 0 & 0 \cdot 0 & 0 \cdot 0 \\ \text { Medium sand } & \ldots & 0 \cdot 13 & 0 \cdot 14 & 0 \cdot 17 & 0 \cdot 13 & 0 \cdot 10 \\ \text { Fine sand ... } & \ldots & 2 \cdot 6 & 2 \cdot 2 & 1 \cdot 9 & 1 \cdot 5 & 0 \cdot 9 \\ \text { Very fine sand } & \ldots & 48 \cdot 6 & 49 \cdot 1 & 46 \cdot 7 & 45 \cdot 5 & 42 \cdot 2 \\ \text { Silt } \quad \ldots & \ldots & 33 \cdot 4 & 32 \cdot 5 & 32 \cdot 0 & 31 \cdot 0 & 34 \cdot 2 \\ \text { Clay } \ldots & \ldots & 15 \cdot 3 & 16 \cdot 1 & 19 \cdot 3 & 21 \cdot 9 & 22 \cdot 6 \\ \text { Hygroscopic coefficient } & 10 \cdot 9 & 10 \cdot 9 & 12 \cdot 2 & 12 \cdot 0 & 11 \cdot 4\end{array}$

Chemical analyses show that carbonates are practically absent in the surface soil, but increase rapidly with depth, and in the hardpan layer, which appears somewhat chalky in colour, they often reach concentrations of 5 or 6 per cent. Table 4 shows that the soils are not acid, the carbon dioxide increasing very rapidly with depth and being very high at 2 to 4 feet. These 


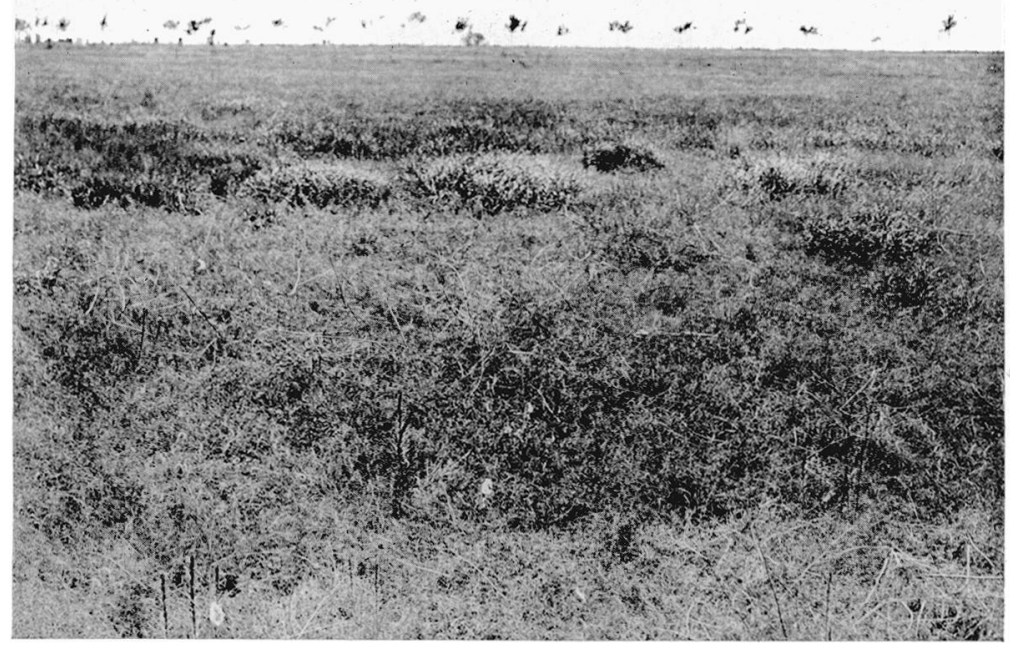

(a) Mixed prairie near Phillipsburg, Kansas, showing the short-grasses (Bulbilis ductyloides and Bouteloua gracilis) in the foreground alternating with or forming an understory to the taller Andropogons. Photographed August 28, 1922.

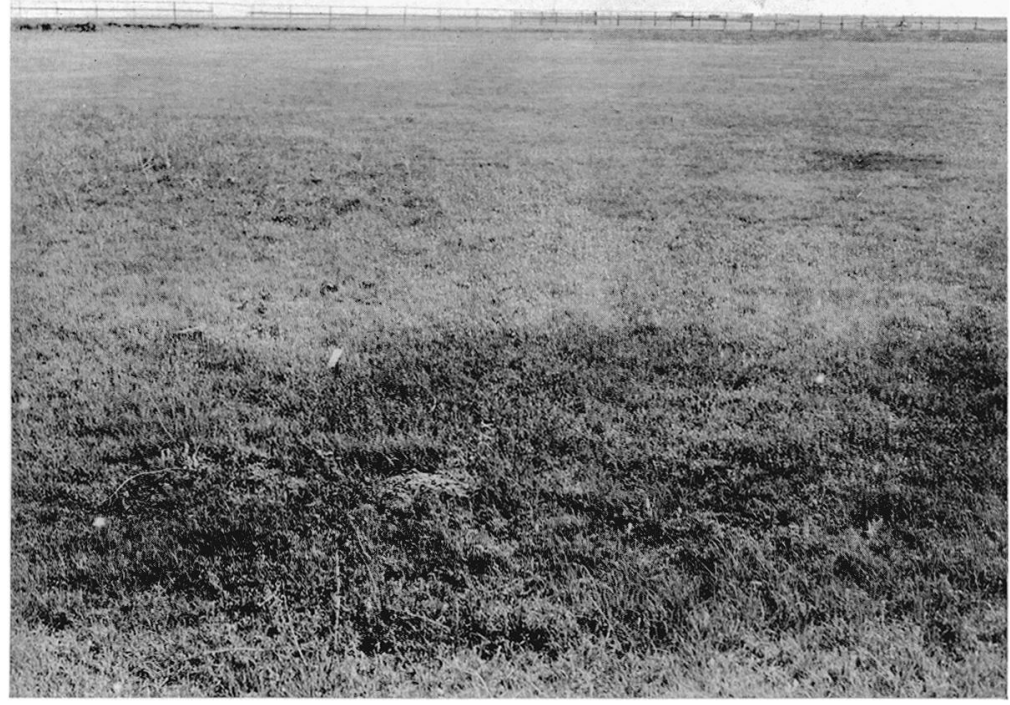

(b) General view in the short-grass plains at Burlington, Colorado, showing closed mats of Bulbilis dactyloides mixed with Bouteloua gracilis. Note the scarcity of other vegetation. Photographed July i 5 , 1920. 
soils are rich in phosphorus and potassium and have a sufficient supply of nitrogen. Thus all the critical elements are present in abundance.

TABLE 4. Chemical analyses ${ }^{1}$ of soils from Burlington, Colorado.

\begin{tabular}{|c|c|c|c|c|c|c|}
\hline & \multicolumn{5}{|c|}{ Depth of sample in feet } \\
\hline & & $\begin{array}{c}0 \cdot 0-0.5 \\
\%\end{array}$ & $\begin{array}{c}0 \cdot 5-1 \cdot 0 \\
\%\end{array}$ & $\begin{array}{l}1-2 \\
\%\end{array}$ & $\begin{array}{l}2-3 \\
\%\end{array}$ & $\begin{array}{l}3-4 \\
\%\end{array}$ \\
\hline Acidity & & None & None & None & None & None \\
\hline Carbon dioxide & $\ldots$ & 0.03 & $0 \cdot 30$ & $1 \cdot 71$ & $2 \cdot 10$ & $2 \cdot 60$ \\
\hline Volatile matter & $\ldots$ & $4 \cdot 67$ & $3 \cdot 13$ & $3 \cdot 11$ & $3 \cdot 34$ & $2 \cdot 84$ \\
\hline Phosphorus pento & xide & $0 \cdot 189$ & $0 \cdot 504$ & $0 \cdot 428$ & 0.406 & 0.525 \\
\hline Sulphur trioxide & $\ldots$ & $0 \cdot 007$ & $0 \cdot 017$ & $0 \cdot 006$ & $0 \cdot 006$ & 0.005 \\
\hline Potassium oxide & $\ldots$ & $2 \cdot 32$ & $2 \cdot 39$ & $2 \cdot 45$ & $2 \cdot 51$ & $2 \cdot 22$ \\
\hline Nitrogen ... & $\ldots$ & $0 \cdot 184$ & $0 \cdot 130$ & $0 \cdot 101$ & 0.086 & 0.084 \\
\hline
\end{tabular}

In this hard fine-textured soil water penetrates very slowly and run-off is usually high. Shantz (1911) has shown that the average run-off from the short-grass sod at five stations in this region was 37 per cent. of the total rainfall, while the maximum run-off reached 55 per cent. Thus, the actual precipitation (17 inches) tells little of the efficient rainfall. After heavy rains three days were required for the water to penetrate to a depth greater than 6 inches. The excellent root development of native plants in the surface 1.5 to 2.5 feet of soil fits them to absorb water readily, and thus helps to prevent deep water penetration.

Determinations of water-content throughout a series of years (1920-1923) show that the soil is seldom moist below two feet, while regularly by midsummer the holard above this level is frequently reduced to the hygroscopic coefficient. Then the short-grass cover dries out and "cures" on the ground.

Closed mats of Bulbilis dactyloides, usually mixed with Bouteloua gracilis, make up fully 90 per cent. of the vegetation, forming a carpet seldom over 4 inches deep, exclusive of flower stalks (Pl. II $b$ ). These grasses with their widely spreading roots occupy the soil so thoroughly that relatively few important subdominants are present. Most conspicuous among these, and increasing in abundance where overgrazing has occurred, are Aristida purpurea, Opuntia camanchica, O. fragilis, O. polyacantha, Festuca octoflora, Plantago purshii and Schedonnardus paniculatus. Erysimum asperum and Psoralea tenuiflora are often abundant.

Small, poorly developed societies of Astragalus crassicarpus, Malvastrum coccineum and Ratibida columnaris are infrequent. Agropyrum glaucum under the severe competition with the short-grasses is dwarfed in habit and forms flower stalks sparingly. Decreased size, vigour and number are evident among most of the above species when compared with their growth in more favourable habitats.

1 Phosphorus determinations were made by digestion with $\mathrm{HNO}_{3}$ and $\mathrm{HF}$; sulphur by fusion with $\mathrm{Na}_{2} \mathrm{O}_{2}$; potassium by fusion with calcium carbonate; and nitrogen by the modified Gunning method. 


\section{2}

While some of the species of the meagre flora are rooted entirely in surface soils, others, especially the dominant grasses and the legumes, reach depths of 4 feet or more. However, when compared with the great depth reached by species in the moist subsoil of the true prairie, even these are relatively shallow.

\section{COMPARISON OF ENVIRONMENTS.}

A glance at the distribution of the mean annual precipitation (Fig. 2) shows clearly that most of the moisture falls during the growing season and only about one-tenth during the three winter months. Such a seasonal distribution of moisture is very favourable for the growth of grasses. The normal decrease of 5 inches at Phillipsburg under that at Lincoln, and 6 inches decrease at Burlington under that of the mixed prairie station, is quite evenly

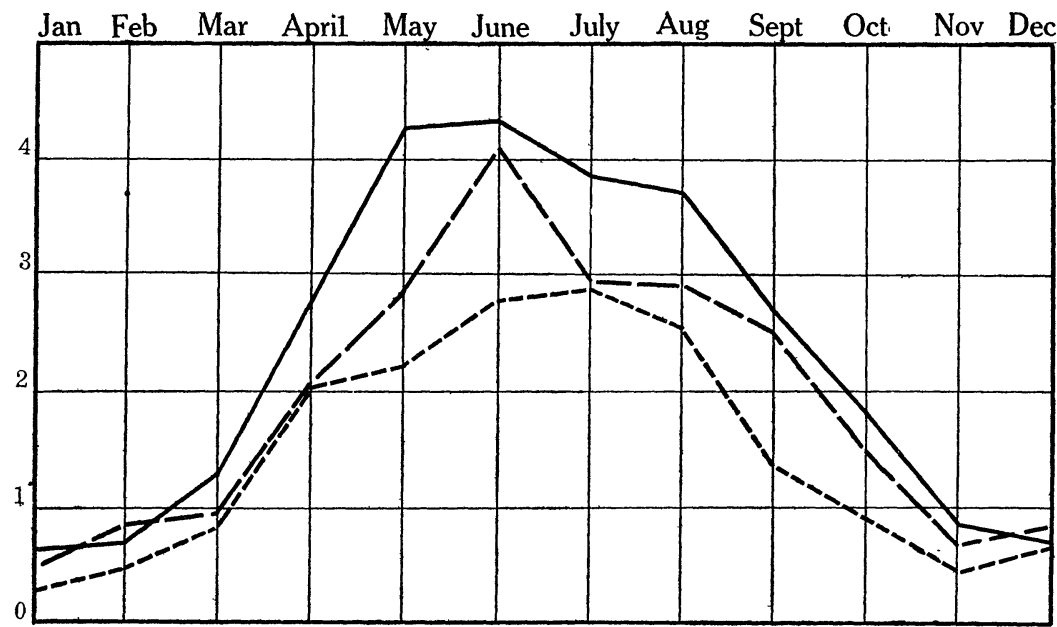

Fig. 2. Graphs showing the distribution of the mean annual precipitation in inches at Lincoln (solid line), Phillipsburg (long broken lines), and Burlington (short broken lines).

distributed through the year. Moreover, the type of rainfall is quite similar throughout, consisting usually of heavy showers, often of rather short duration. This, however, is more marked upon the high plains than eastward where the rains are more general. At all stations it results in much run-off, but this is particularly heavy in the compact soil at Burlington. Moreover, westward, relatively more of the precipitation falls in light showers of $\cdot 20$ inch or less, which are of practically no value in increasing the holard. At each station, the holard has, in general, been very similar at any particular time during the three seasons (1920-22), and the comparison of a single season's data will suffice here (Table 5).

An examination of the table shows that at all times at Lincoln a sufficient amount of water was available at all depths to promote good growth. At the mixed-prairie station July and early August were periods of drought and, at times, of actual deficiency. The holard at Burlington was favourable until 


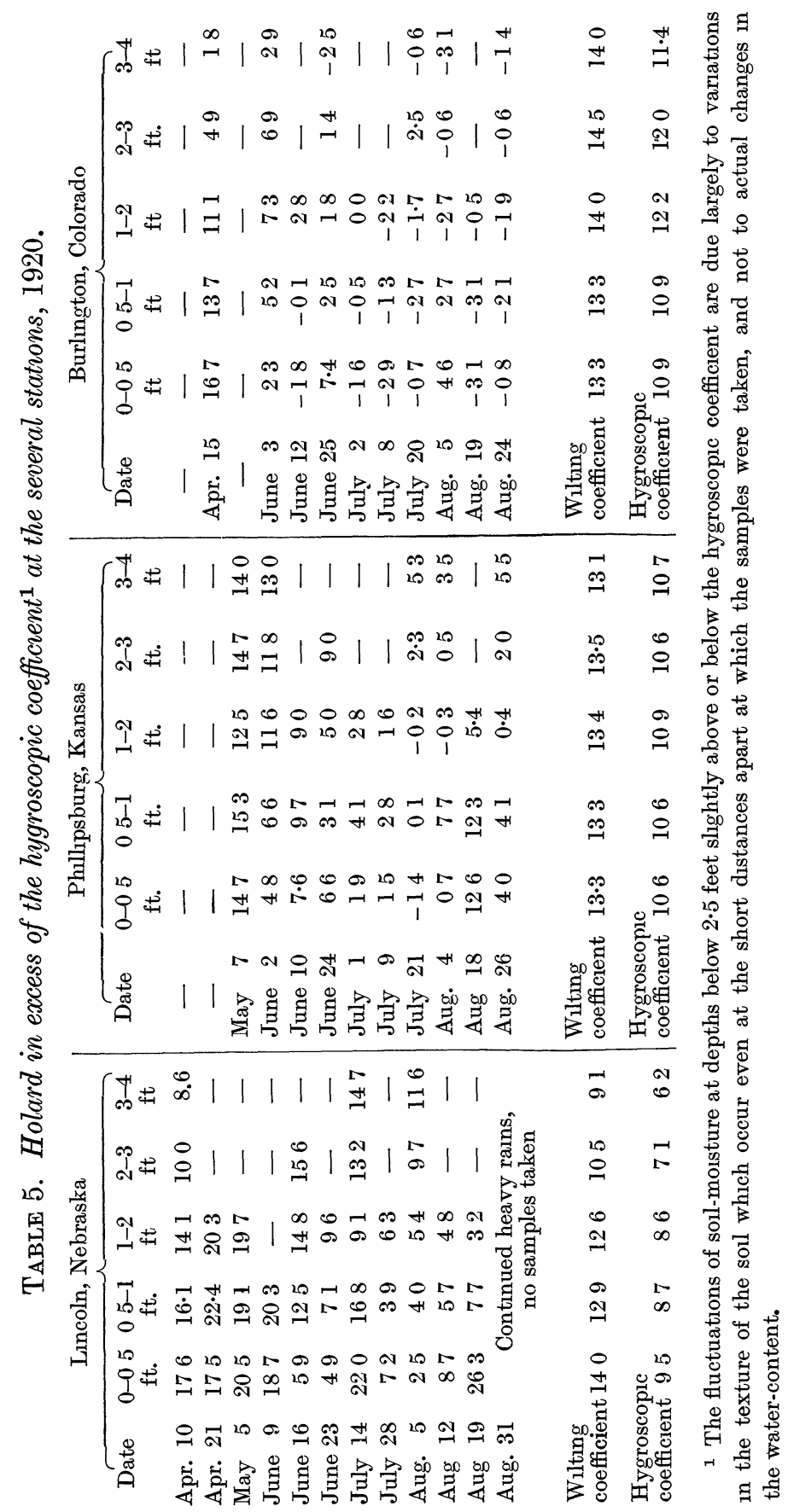




\section{Plant Production as a Measure of Environment}

June, but after this time marked deficiencies were of frequent occurrence. However, the value of water-content to the plant is not determined entirely by its quantity, but largely also by its rate of dissipation both through the plant and by surface evaporation. These in turn are controlled by humidity as affected by temperature, wind, etc., all of which are more or less perfectly integrated in the evaporating power of the air.

Because of differences in elevation, which more than offset those of latitude, spring usually opens about 7 to 10 days later at Phillipsburg, and 18-23 days later at Burlington than at Lincoln. These stations are 800 and 3000 feet higher respectively, than Lincoln. The average daily air temperature ${ }^{1}$ for 1920 (which is in general agreement with that of other seasons) is given in Fig. 3. The air was usually $5^{\circ}$ to $7^{\circ} \mathrm{F}$. colder at Burlington than at Phillipsburg, while at Lincoln it was generally warmer than that at Phillipsburg. Moreover the average day air temperatures were highest at Lincoln and lowest at Burlington, and this same general relation held for average night temperatures. Night temperatures at Burlington varied from $45^{\circ}$ to $67^{\circ} \mathrm{F}$. Such low temperatures, while unfavourable for growth, have a profound effect upon humidity, which factor, with the holard, is of paramount importance, differences of temperatures as such probably having little effect upon the type of grassland.

The average daily soil temperatures at a depth of 6 inches are given in Fig. 4. Soil temperatures were highest at Lincoln $\left(70^{\circ}\right.$ to $77^{\circ} \mathrm{F}$.), and lowest at Burlington $\left(64^{\circ}\right.$ to $72^{\circ} \mathrm{F}$.) during the first half of June, but by the last week in June this relation was reversed, the soil at Burlington remaining warmer throughout the season. The average weekly differences were often $6^{\circ}$ to $8^{\circ} \mathrm{F}$., the soil at Lincoln being coldest, that at Phillipsburg intermediate, while the dry soil at Burlington had the highest temperatures.

The daily range of both temperature and humidity is much greater at the Burlington station than at Lincoln. The average day and night humidities for 1920 are given in Fig. 5. Conditions at Phillipsburg are somewhat intermediate. This combination of high temperature and low humidity, which occurs rather regularly in the afternoons at Burlington, when coupled with dry soil, is a condition very unfavourable for plant-growth.

Wind movement is much greater at Burlington than at either of the other stations, and is an important factor in desiccating both plants and soil. An average day velocity of 8 to 10 miles per hour (at a height of 0.5 metre) is quite usual, while periods lasting several days when the velocity reaches 20 or 30 miles per hour are not uncommon. The amount of wind is less at Phillipsburg and much less at Lincoln (for example, 4 miles per hour average daily from July 13 to September 19, 1916, cf. Weaver, 1919, 23).

1 The average for the day temperatures was determined from the weekly record-sheets of the thermographs by adding the temperatures beginning at $8 \mathrm{a} . \mathrm{m}$. and every 2 hours thereafter until 6 p.m. for each day and dividing the sum by the total number of 2 -hour intervals. Those for the night intervals were calculated in a similar manner, beginning at 8 p.m. and including the readings until 6 a.m. Humidity was determined in a similar manner. 
J. E. Weaver

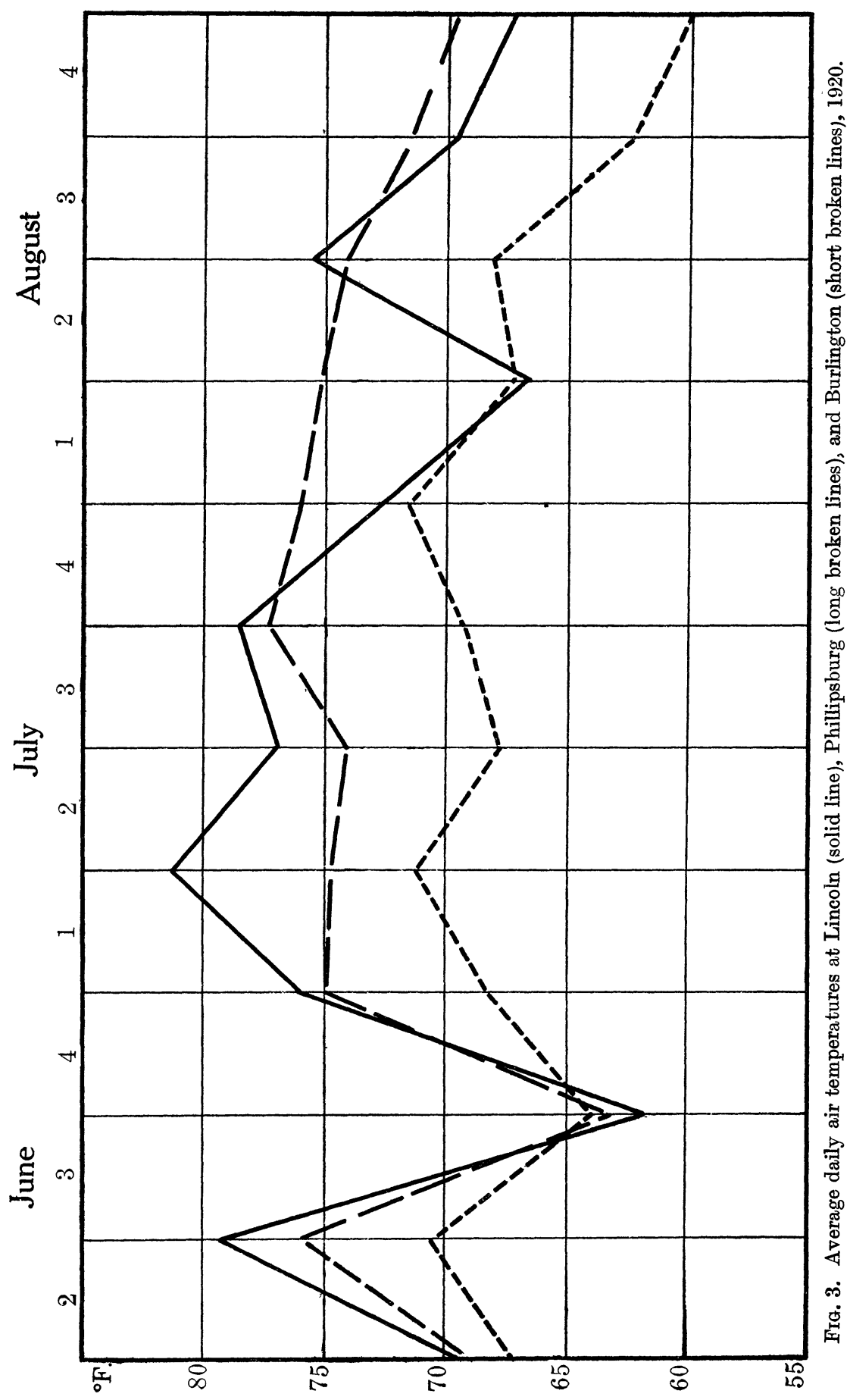


216 Plant Production as a Meäsure of Environment

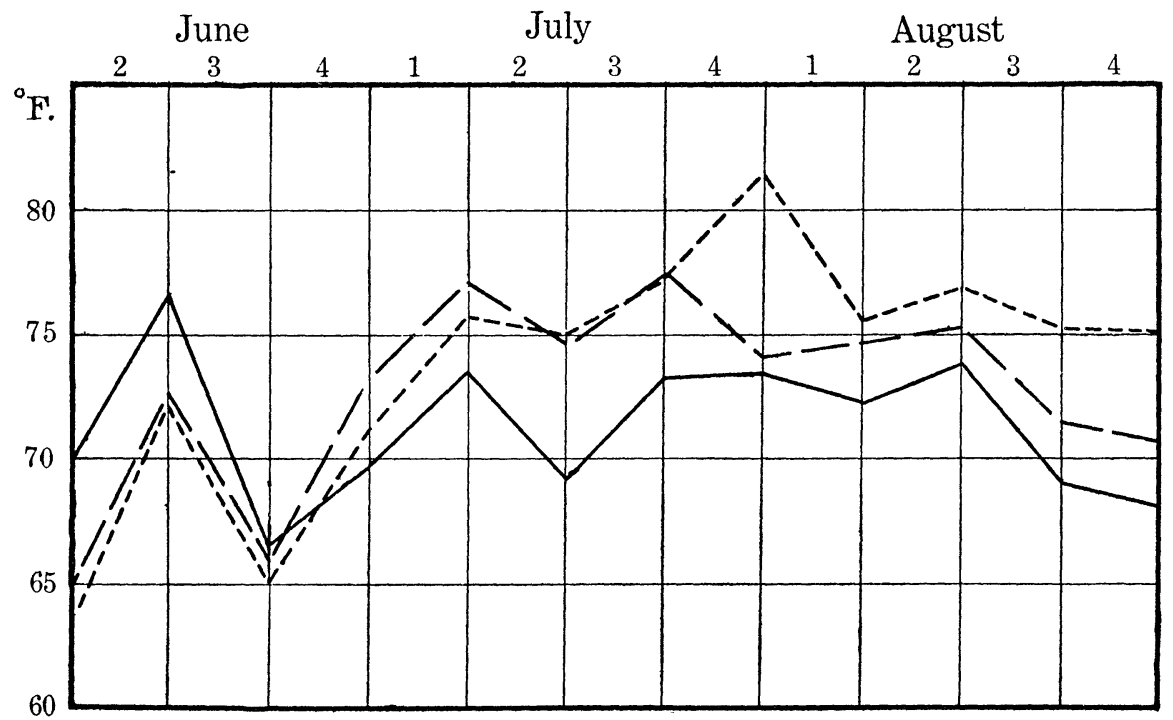

FIG. 4. Average daily soil temperatures at Lincoln (solid line), Phillipsburg (long broken lines), and Burlington (short broken lines), 1920.

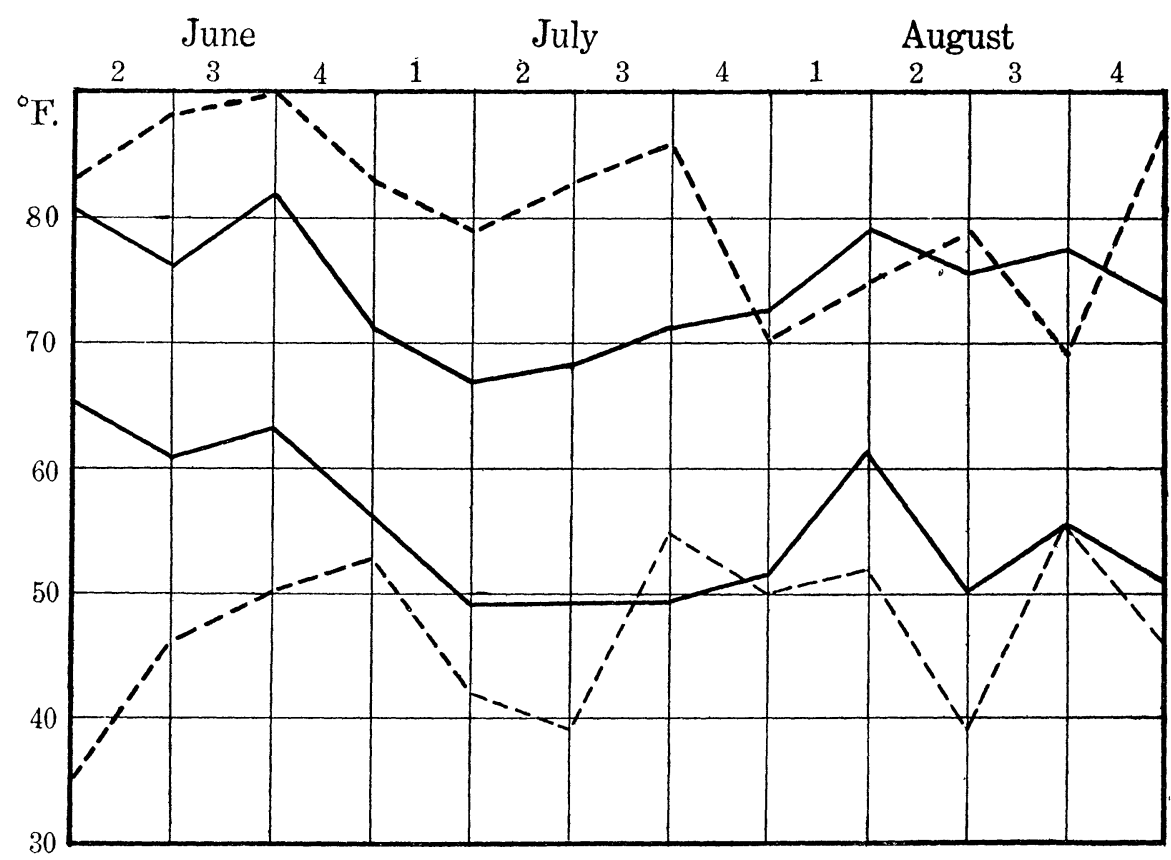

Fra. 5. Average day humidity (lower lines) and average night humidity (upper lines) at Lincoln (solid lines) and Burlington (broken lines), 1920. 
The evaporating power of the air, which integrates, to a certain degree, the factors of radiant energy, humidity, and wind movement, was greatest throughout the season of 1920 at Burlington (23 to 60 c.c. average daily evaporation from white cylindrical, non-absorbing atmometers), intermediate at Phillipsburg (11 to 32 c.c.), and least at Lincoln (9 to 25 c.c.). Cf. Fig. 6. Similar constant differences of evaporation rates were obtained the following seasons.

Thus, the conditions for plant-growth as regards rainfall, holard, temperature, humidity, wind, and evaporation are normally most favourable at Lincoln, intermediate at Phillipsburg, and least favourable at Burlington. These conditions are indicated by the native vegetation and borne out by the growth of both native and cultivated plants.

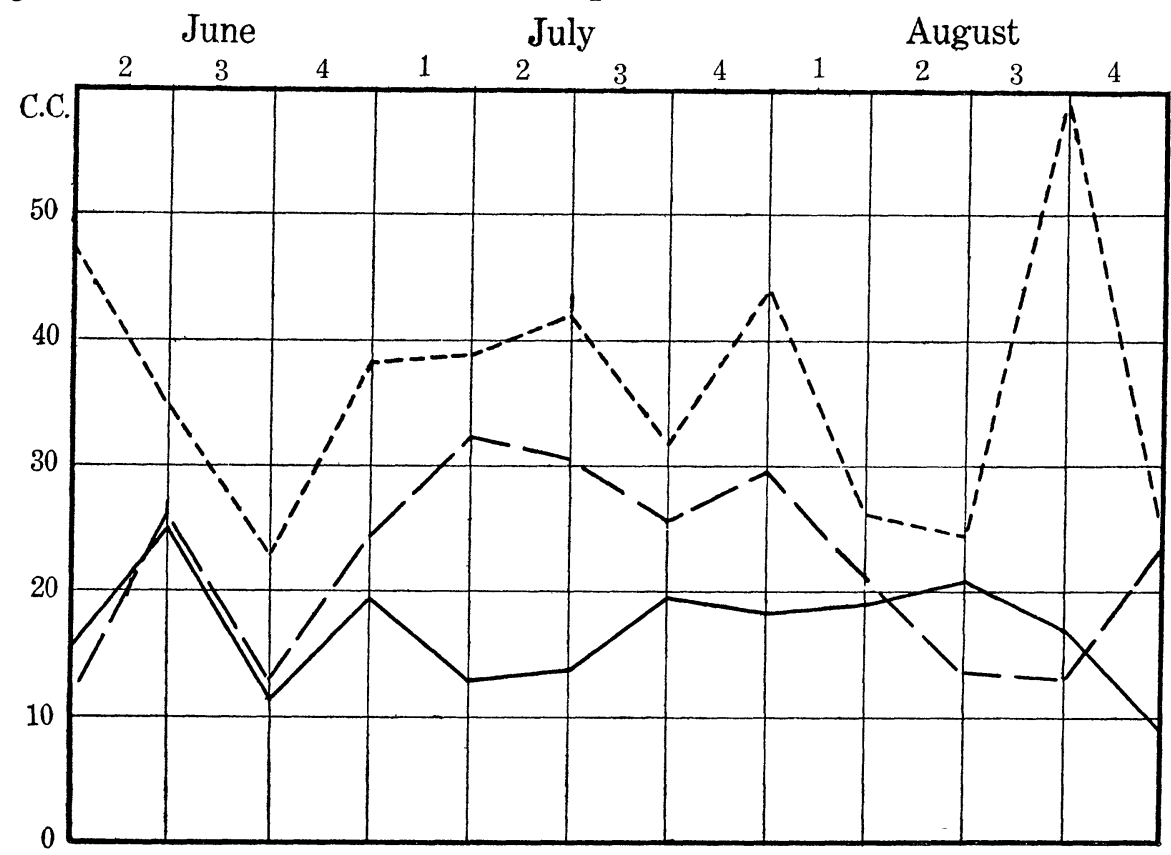

Fra. 6. Average daily evaporation at Burlington (short broken lines), Phillipsburg (long broken lines), and Lincoln (solid lines), 1920.

EXPERIMENTAL METHODS AND RESULTS, 1920.

The methods employed were to select a large number of metre-quadrats in typical undisturbed areas in the climax vegetation. The height and density of the vegetation, the abundance of dominant and subdominant species, etc., were recorded, and photographs were made of representative quadrats. The vegetation was then removed by cutting it near the surface of the soil with a hand clipper, after which it was collected, shipped to the laboratories of the University of Nebraska where it was thoroughly air dried, and the plant production determined on the basis of dry weight. Thus the growth of vegetation 


\section{Plant Production as a Measure of Environment}

as a unit as well as the comparative importance of the dominants in the various associations, was determined.

Complete data on the earlier cuttings in 1920 are given in Tables 6,7 and 8 (cf. also Pls. III and IV).

TABLE 6. Quadrats cut July 7, 1920, at Burlington, Colorado.

\begin{tabular}{|c|c|c|}
\hline Quadrat & Description & $\begin{array}{c}\text { Dry } \\
\text { in } g\end{array}$ \\
\hline 1 & $\begin{array}{l}\text { Pure growth of staminate Bulbilis, closed mat; average height leaves } 4^{\prime \prime} \text {; } \\
\text { flower stalks } 5-6^{\prime \prime}\end{array}$ & \\
\hline 2 & Do. with average height leaves $3^{\prime \prime}$; flower stalks $4^{\prime \prime}$ & \\
\hline 3 & Do. only pistillate; average height leaves $3^{\prime \prime}$ & \\
\hline 4 & $\begin{array}{l}\text { Mostly pure closed mat of Bouteloua gracilis; leaves } 5-7 \text { "; no flower stalks; } \\
\text { one Sitanion elymordes and a few Malvastrum coccineum }\end{array}$ & \\
\hline 5 & Dense mat of Bouteloua gracilis, 5-7" high & \\
\hline 6 & Bouteloua gracilis with a little Bulbilis and Malvastrum & \\
\hline 7 & Pure Bouteloua gracilis in very open mats, only $2-4^{\prime \prime}$ high, no flower stalks & \\
\hline 8 & Nearly pure Bouteloua gracilis in dense mats about $5^{\prime \prime}$ high & \\
\hline 9 & $\begin{array}{l}\text { Very open mats of Bouteloua gracilis, } 2-4^{\prime \prime} \text { high One Schedonnardus } \\
\text { paniculatus }\end{array}$ & \\
\hline 10 & Pure staminate Bulbilis; grazed in 1919 ; leaves $4-5^{\prime \prime}$, flower stalks 5-6" & \\
\hline 11 & $\begin{array}{l}\text { Open mats of pistillate Bulbilis } 3^{\prime \prime} \text { high; Festuca octoflora abundant, } 4^{\prime \prime} \text { high, } \\
\text { ripe; grazed } 1919\end{array}$ & \\
\hline 12 & Open mats of pistillate Bulbilis $4^{\prime \prime}$ high & \\
\hline 13 & Closed mats of pistillate Bulbilis 4-5" high; grazed 1919 & 120 . \\
\hline 14 & Do., only staminate; flower stalks $5-6^{\prime \prime}$ & \\
\hline 15 & talks 5-6" & 139 \\
\hline 16 & Do., only staminate; flower stalks $3-4^{\prime \prime}$ high & 93 \\
\hline 17 & Bulbilis with some Agropyrum glaucum and a little Bouteloua gracilis & 223 \\
\hline 18 & $\begin{array}{l}\text { Pure Agropyrum glaucum; flower stalks 18-26" high; burned 1919. Area } \\
\text { formerly broken }\end{array}$ & \\
\hline 19 & 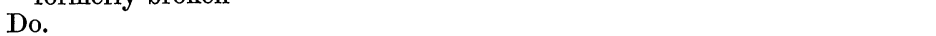 & 422 \\
\hline 20 & Do. & \\
\hline 0 & Do. & 37 \\
\hline 2 & alf Bouteloua gracilis; closed mats $4-5^{\prime \prime}$ high & 196 \\
\hline 23 & Bulbilis mixed with one-third Bouteloua gracilis, $3-4^{\prime \prime}$ high & 105 . \\
\hline 24 & Bulbilis slightly mixed wi & \\
\hline & ; leaves $10^{\prime \prime}$; flower stalks $17^{\prime \prime}$ & 182 \\
\hline 26 & of Bulbilis and Bouteloua & 180 \\
\hline 27 & Bulbilis mixed with Bouteloua & \\
\hline 28 & Agropyrum glaucum mixed wit & \\
\hline 29 & ome Bouteloua $6^{\prime \prime}$ & 294 \\
\hline 30 & Mixed Bouteloua and Bulbilis, about half of each; 1 Chrysopsis villosa & 182 \\
\hline
\end{tabular}

TABLE 7. Quadrats cut July 9, 1920, at Phillipsburg, Kansas.

1 Pure Bouteloua gracilis leaves 5-7" high, some Malvastrum, 1 Allionia linearis

2 Bouteloua gracilis with a little Bulbilis, 1 Ratibida columnaris, a little Plantago purshii

3 Bouteloua gracilis with a little Bulbilis, 1 Allionia, 1 Ratibida, and some Malvastrum; a little Festuca octoflora

4 Closed mat of staminate Bulbilis, leaves 6-7", flower stalks 8-9", burned 1919

Very open mat of staminate Bulbilis, leaves 3-4", burned 1919

Pure pistillate Bulbilis, leaves 4-7", undisturbed for years

Agropyrum glaucum, 32" high, dense sod

Do.

Pure Agropyrum glaucum, flower stalks $40^{\prime \prime}$ high

10 Do. 1 Psoralea floribunda, Aster multiflorus

12 About half Bulbilis, forming a layer under Andropogon furcatus

13 Understory of Bulbilis dominating half of quadrat, 6-8", Bouteloua acemosa, Andropogon furcatus 


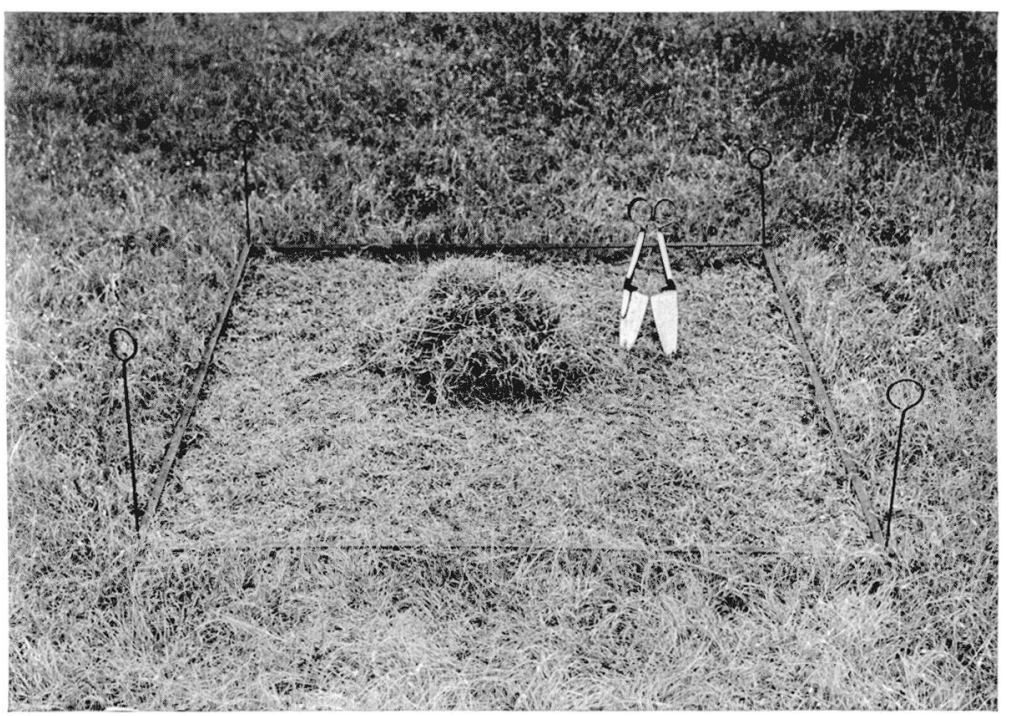

(a) Typical cut-quadrat in short-grass plains vegetation, July 7, 1920. bulbilis dactyloides with Boutcloun gracilis.

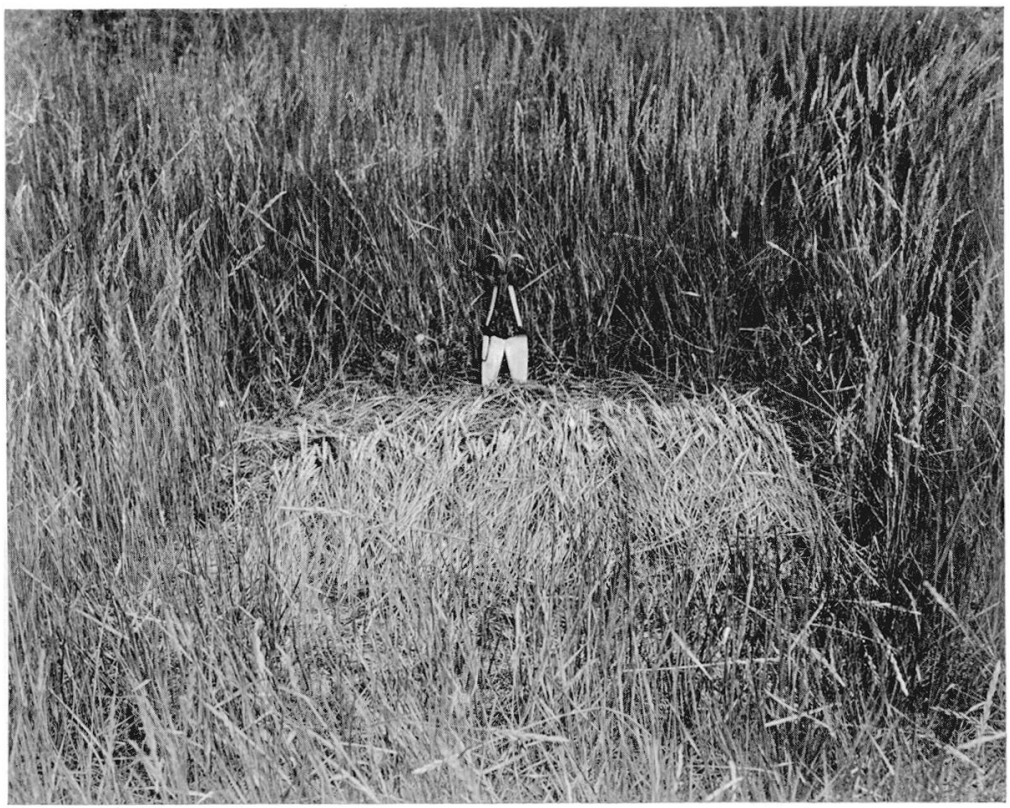

(b) Cut-quadrat of Agropyrum slaucum, Burlington, Colorado, July 7, I920.

WEAVER-Plant Production as a Measure of Environment. 


\section{JOURNAL OF ECOLOGY}

Vol. XII, Plate IV

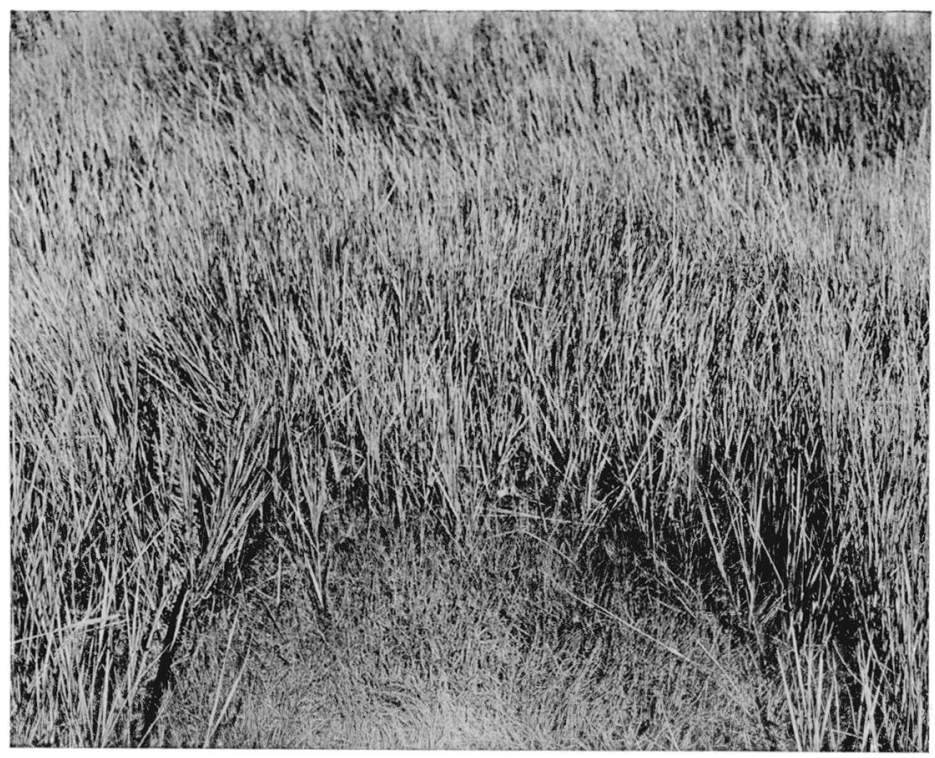

(a) Mixed-grass quadrat at Phillipsburg, Kansas, July 8, 1920. Agropyrum glaucum invading an area of Bulbilis dactyloides.

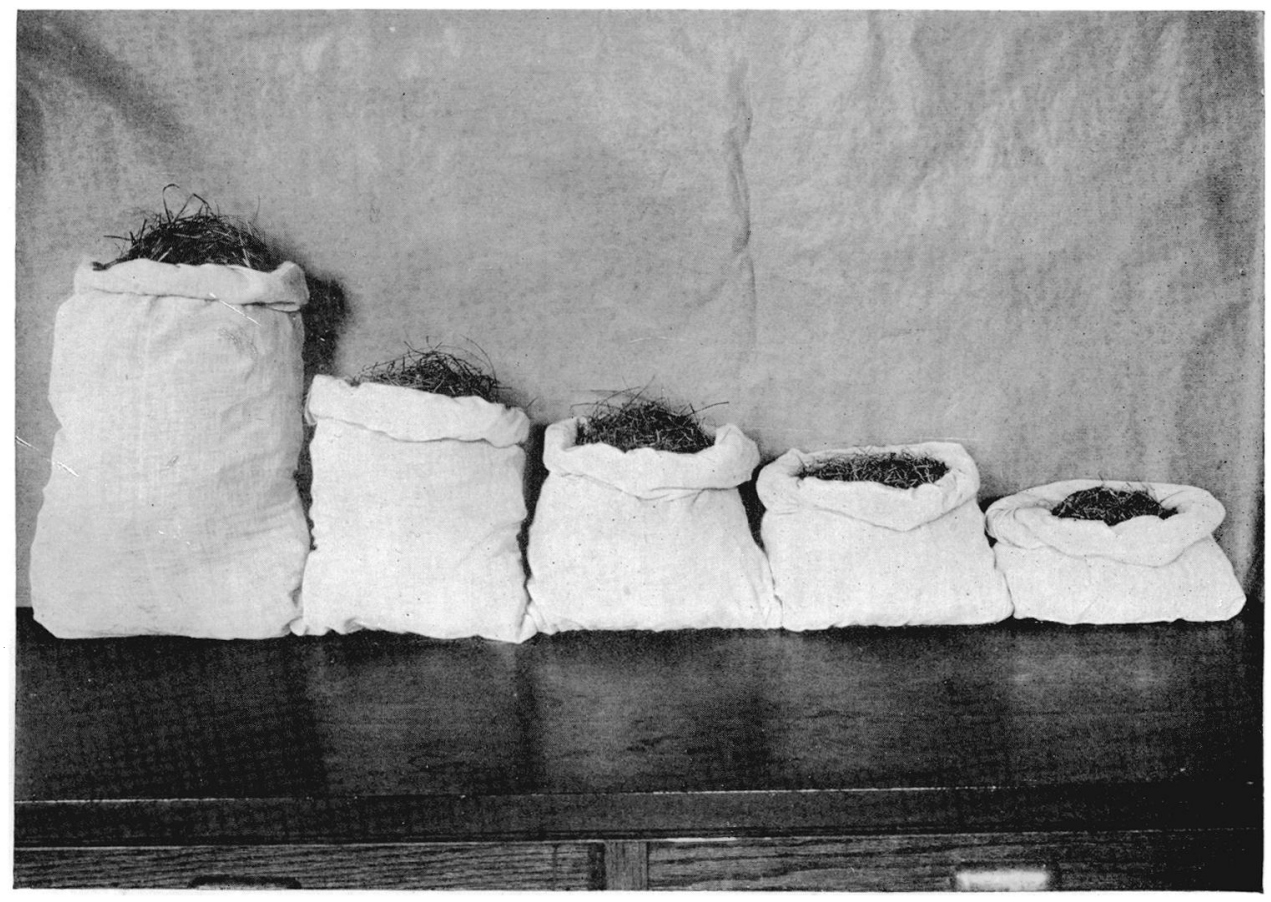

(b) An average yield from a square metre of grassland. From right to left: Buffalo grass from Burlington and Phillipsburg, mixed tall- and short-grasses from Phillipsburg, mixed tall-grasses from high prairie and low prairie at Lincoln. 
Table 7 (continued).

\begin{tabular}{|c|c|}
\hline Quadrat & Description \\
\hline 14 & $\begin{array}{l}\text { Andropogon furcatus, A. scoparius and Elymus canadensis mixed, average } \\
\text { height } 20^{\prime \prime}\end{array}$ \\
\hline 15 & Do. with a little Psoralea floribunda \\
\hline 16 & Andropogon furcatus and $A$. scoparius, $15-24^{\prime \prime}$ high \\
\hline 17 & $\begin{array}{l}\text { Bunches of Andropogon scoparius, Elymus canadensis, some Aster multi- } \\
\text { florus }\end{array}$ \\
\hline 18 & $\begin{array}{l}\text { Andropogon furcatus with some } A \text {. scoparius and Bouteloua racemosa, a little } \\
\text { Solidago rigida and some Psoralea floribunda }\end{array}$ \\
\hline 19 & $\begin{array}{l}\text { Agropyrum glaucum } 40^{\prime \prime} \text { high with Bulbilis understory } 6^{\prime \prime} \text { high in one-half } \\
\text { of quadrat }\end{array}$ \\
\hline 20 & Pure Andropogon furcatus, 20" high, burned 1919 \\
\hline 21 & Do., but only $10^{\prime \prime}$ tall in centre of quadrat \\
\hline 22 & Pure Andropogon furcatus, 18-20" high \\
\hline 23 & $\begin{array}{l}\text { Elymus canadensis mixed with some Sporobolus longifolius and species of } \\
\text { Carex, average height } 37^{\prime \prime}\end{array}$ \\
\hline 24 & Nearly pure Elymus canadensis, $36^{\prime \prime}$ high \\
\hline 25 & Sporobolus longifolius with a little $\Gamma^{1}, \mu_{1} \cdots \cdots$. luight $24^{\prime \prime}$ \\
\hline 26 & $\begin{array}{l}\text { About half Andropogon furcatus, l, } 111 . \%, \ldots, \ldots \text { canadensis, with a little } \text { Aster } \\
\text { multiflorus }\end{array}$ \\
\hline
\end{tabular}

Dry weight

in grams

$405 \cdot 7$

$525 \cdot 2$

$596 \cdot 3$

$281 \cdot 3$

$679 \cdot 2$

$720 \cdot 0$

$445 \cdot 2$

$547 \cdot 7$

$523 \cdot 7$

$457 \cdot 1$

$376 \cdot 2$

$617 \cdot 2$

TABLE 8. Quadrats cut July 13, 1920, at Lincoln, Nebraska.

Quadrat Description
1 Stipa spartea, Koeleria cristata, Poa pratensis and Andropogon scoparius, average height $14^{\prime \prime}$

2 Mixed Stipa spartea, Koeleria cristata, Poa pratensis, Carex pennsylvanica and $C$. meadii, average height 14", a little Psoralea floribunda

3 About the same mixture as in the preceding, average height 23"

4 Andropogon furcatus, A. scoparius, with Poa pratensis, Carex pennsylvanica and 1 Amorpha canescens

5 About the same as preceding with Bouteloua racemosa, average height 14"

6 Stipa spartea and Andropogon furcatus mixed with Poa and 1 Baptisia bracteata, average height of leaves $18^{\prime \prime}$

7 Stipa and Poa mixed, 1 Psoralea floribunda, 3 Brauneria pallida

8 Mixed Andropogon furcalus, Stipa and Poa, 4 Asclepias verticillata, 2 Helianthus rigidus, average height of grasses, $25^{\prime \prime}$

9 Mostly Andropogon furcatus with some Poa, 25", 5 Helianthus rigidus, 1 Salvia pitcheri, 1 Physalis heterophylla

10 Andropogon furcatus, mixed with Poa and Agropyrum glaucum, considerable Psoralea and a little Salvia

11 Same grass mixture as preceding, with a little Bouteloua racemosa

12 Andropogon scoparius with Koeleria cristata and Poa, average height 28", some Astragalus crassicarpus, Vicia americana and Psoralea floribunda

13 Koeleria, Andropogon scoparius and A. furcatus, average height 15", 2 Amorpha canescens 3 Psoralea, several Artemisia ludoviciana

14 Mostly Andropogon furcatus, A. scoparius, and Bouteloua racemosa, 15" high, some Aster multiflorus, Linum sulcatum, and Psoralea.

15 Andropogon scoparius, Bouteloua racemosa with some Poa

16 Koeleria, Andropogon scoparius, Poa, Carex pennsylvanica, some Solidago, rigida and Erigeron ramosus

17 Poa mixed with Stipa, Koeleria, Bouteloua racemosa, and Panicum scrib. nerianum, average height, $16^{\prime \prime}$

18 Koeleria dominant, 24" high, a little Andropogon scoparius and $A$. furcatus and Bouteloua racemosa

19 An equal mixture of Andropogon scoparius, Poa, Koeleria and Andropogon furcatus, some Erigeron and Vicia americana

20 Spartina cynosuroides with Poa, average height 25", some Glycyrrhiza lepidota

21 Do., only less Spartina

22 Poa dominant, a little Spartina and Andropogon furcatus 23 Spartina, Andropogon furcatus and Poa with Glycyrrhiza, 2 Aster multiflorus

Spartina dominant, 27" high, Andropogon furcatus and a little Poa

Dry weight

in grams 


\section{Plant Production as a Measure of Environment}

An examination of the tables shows that rather wide differences occur in productiveness of the surface cover in the same area and representative conditions are to be secured only by the use of a large number of carefully selected quadrats. The obtaining of reliable results by this method, as in similar ecological studies, assumes a thorough knowledge of the plant communities rather than random selection on the part of the investigator. However, the markedly higher yields of the different types of vegetation (viz. short-grasses, mixed tall- and short-grasses, etc.) with an increase in soil moisture is at once apparent. The short-grasses at Burlington (quadrats 1-16) averaged 103 grams per square metre; those at Phillipsburg (quadrats 1-6) 290 grams. Wheat-grass (Agropyrum glaucum) at Burlington, which here occurs most abundantly in areas where the short-grass sod has been broken or otherwise disturbed, yielded 398 grams per square metre while at Phillipsburg the yield was 480 grams. Mixed short- and tall-grasses yielded 244 grams per square metre at Burlington, and 470 grams at Phillipsburg. The mixed prairie at Phillipsburg gave a total yield of 439 grams per square metre, true prairie at Lincoln averaged 452 grams. The careful selection of the quadrats is of great importance. The average yield at Phillipsburg (439 grams) exceeded that from the hilltops at Lincoln (361 grams) or even the slopes (429 grams) at this time (July 9), but did not equal that of the lowland which was 564 grams. However, an examination of the factor data shows that late summer drought usually prevails at the western stations and good plant growth is not maintained (Table 5). This fact is nicely illustrated by a second series of quadrats cut August 16-24.

The average yield at Burlington (August 24) was 196 grams (more mixed short- and tall-grass quadrats being included than before), at Phillipsburg only 310 grams, while at Lincoln it was 465 grams.

Adding the 50 quadrats taken at each station during the season, the average total native plant production, proceeding from the drier western station eastward, was 183, 378 and 458 grams respectively.

Crops of oats (Avena sativa), spring wheat (Triticum aestivum), barley (Hordeum vulgare), alfalfa (Medicago sativa) and white sweet-clover (Melilotus $a l b a)$ were also grown in plats adjoining the several grassland stations. Each kind of crop was planted from the same lot of seed and grown under conditions of farm practice common to the several localities respectively.

The relative height of the mature oats and wheat at the several stations is shown in Pl. V as well as the comparative yield from an average square metre. A statement of the height and yield of the cereals (total dry weight of tops) is given in Table 9. The yield is the average of 25-30 metre quadrats taken when the grain was ripe from each of the several plats at the three stations respectively. All of the crops were assembled in the botanical laboratories of the University of Nebraska and thoroughly air dried before weighing. 


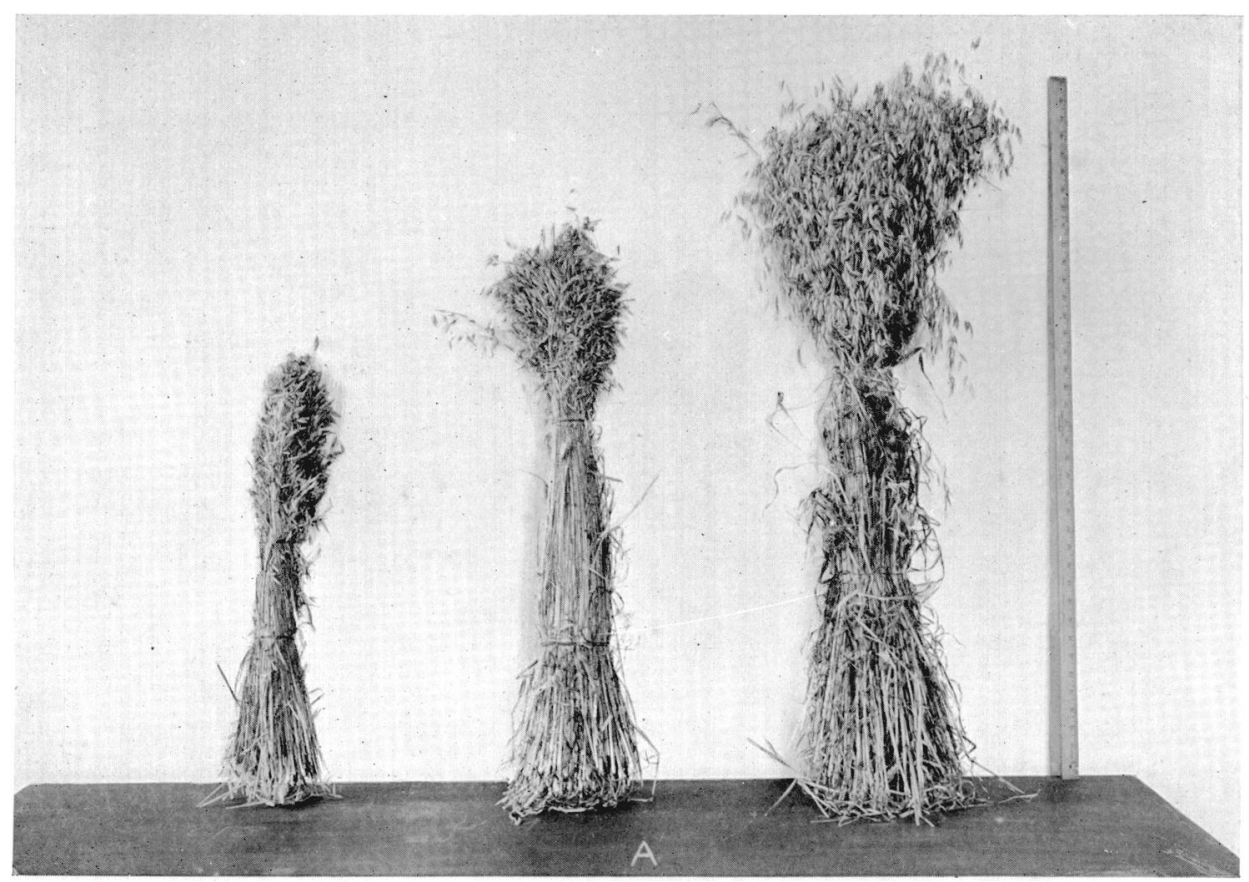

(a) White Kherson oats from a square metre at Burlington (left), Phillipsburg, and Lincoln, 1920.

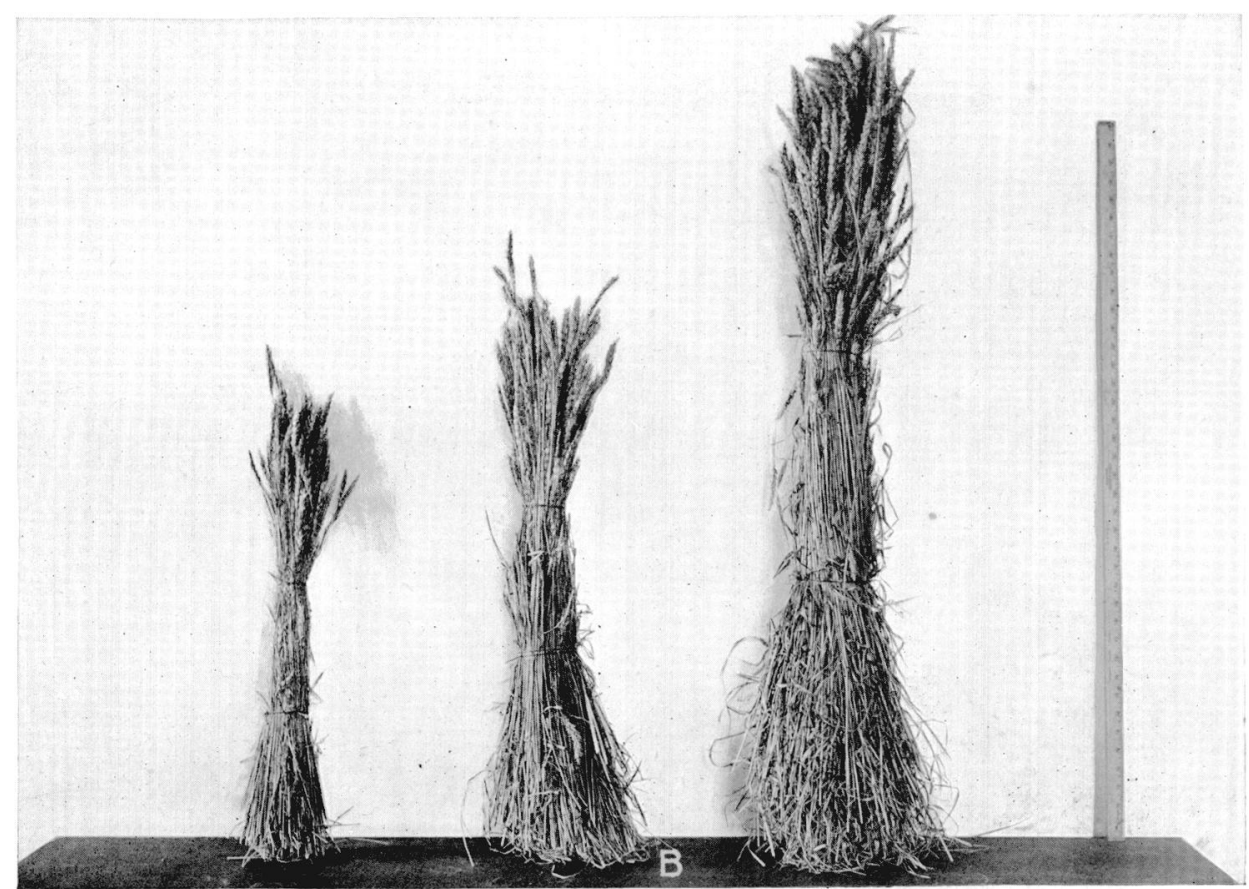

(b) Marquis spring wheat from a square metre at Burlington (left), Phillipsburg, and Lincoln. 
TABLE 9. Summary of cereal crop development, 1920.

\begin{tabular}{|c|c|c|c|}
\hline Crop and station & $\begin{array}{l}\text { Date of } \\
\text { harvest }\end{array}$ & $\begin{array}{c}\text { Average } \\
\text { height }\end{array}$ & $\begin{array}{l}\text { Average yield } \\
\text { in grams } \\
\text { per"sq. m. }\end{array}$ \\
\hline \multicolumn{4}{|l|}{ Oats: } \\
\hline Lincoln & July 12 & $3.0 \mathrm{ft}$. & 706 \\
\hline Phillipsburg & July 20 & $2 \cdot 6$ & 379 \\
\hline Burlington & July 19 & $1 \cdot 5$ & 175 \\
\hline \multicolumn{4}{|l|}{ Wheat: } \\
\hline Lincoln & July 15 & $3 \cdot 2$ & 740 \\
\hline Phillipsburg & July 20 & $2 \cdot 3$ & 322 \\
\hline Burlington & July 19 & $1 \cdot 7$ & 205 \\
\hline \multicolumn{4}{|l|}{ Barley: } \\
\hline Lincoln & July 12 & $2 \cdot 7$ & 607 \\
\hline Phillipsburg & July 17 & $2 \cdot 4$ & 407 \\
\hline Burlington & July 19 & $1 \cdot 7$ & 176 \\
\hline
\end{tabular}

A study of the table shows that the crops are progressively shorter from Lincoln westward and that the average yield is also less.

Four hundred alfalfa plants of average size were carefully selected at each of the stations, cut at the ground line, thoroughly air-dried in the laboratory at Lincoln, and the dry weight ascertained. This was done during July and again in August. The sweet clover was similarly treated, only in this case 300 plants were used (Table 10).

TABLE 10. Development of legumes, 1920.

\begin{tabular}{|c|c|c|c|}
\hline Crop and station & $\begin{array}{l}\text { Date of } \\
\text { cutting }\end{array}$ & $\begin{array}{l}\text { Average } \\
\text { height }\end{array}$ & $\begin{array}{l}\text { Dry weight of } \\
400 \text { av. plants }\end{array}$ \\
\hline \multicolumn{4}{|l|}{ Alfalfa: } \\
\hline Lincoln & July 12 & $1.5 \mathrm{ft}$. & 528 gms. \\
\hline Phillipsburg & July 9 & 0.7 & 292 \\
\hline Burlington & July 8 & $0 \cdot 4$ & 122 \\
\hline \multicolumn{4}{|l|}{ Sweet clover: } \\
\hline Lincoln & July 12 & $2 \cdot 0$ & 840 \\
\hline Phillipsburg & July 9 & $1 \cdot 3$ & 461 \\
\hline Burlington & July 8 & $0 \cdot 4$ & 213 \\
\hline \multicolumn{4}{|l|}{ Alfalfa: } \\
\hline Lincoln & Aug. 9 & $1 \cdot 8$ & 739 \\
\hline Phillipsburg & Aug. 4 & $1 \cdot 2$ & 601 \\
\hline Burlington & Aug. 5 & $0 \cdot 6$ & 214 \\
\hline \multicolumn{4}{|l|}{ Sweet clover: } \\
\hline Lincoln & Aug. 9 & $2 \cdot 5$ & 1103 \\
\hline Phillipsburg & Aug. 4 & $1 \cdot 7$ & 869 \\
\hline Burlington & Aug. 5 & 0.8 & 323 \\
\hline
\end{tabular}

These data show that, as with cereal crops, both height growth and dry weight correlate directly with available water-content, which is greatest at Lincoln and least at Burlington. 


\section{EXPERIMENTS DURING 1921. \\ Envirunmental Conditions.}

The season of 1921 at Lincoln was quite favourable as to precipitation. Rainfall for April, June and July was slightly above normal while August was slightly below normal as was May also (Fig. 7). An examination of the records shows that the showers were exceptionally well distributed, no marked drought periods occurring, and at no time did the vegetation become dry or brown even on the driest ridges.

At Phillipsburg an excess of $0 \cdot 14,0.98$, and 1.30 inches rain fell during April, May and June respectively. The July precipitation was slightly above normal and that of August and September slightly below (Fig. 8). A drought period occurred between June 9 and 28, during which time no efficient moisture fell. At Burlington the precipitation for April was nearly twice normal (and 0.86 inch more than at Lincoln). May fell 0.91 inch below normal; June was somewhat above $(0.58$ inch); July had less than half the usual amount (only 1.15 inches), August had an excess of 1.19 inches, but September a deficit of more than one-half the normal (Fig. 9). No efficient rainfall occurred (i.e. showers of over 0.15 inch) between March 7 and April 15, April 17 and May 19, June 23 and July 4, and July 8 and August 7. By July 24 the short-grasses were about half dried and brown, while two weeks later not only the grama and buffalo grasses were curled and brown, but the wheat-grass heads were dry as well.

These conditions are reflected in the holard at the several stations (Table 11). At Lincoln a margin of 5 per cent. or more (usually 8 or 10) existed at all times and at all depths to 4 feet. At Phillipsburg the echard was approached once in July and twice in August, actually reaching the danger mark to a depth of 4 feet late in that month. Conditions at Burlington were, as usual, much worse. At no time was water available in the third or fourth foot, while after June 30 it was depleted repeatedly above the hardpan (at about 2 feet).

The average daily evaporation at the several stations is shown in Fig. 10. The rather uniform rates at Lincoln (8 to 27 c.c. average daily) as compared with the erratic and excessively high ones at Burlington (18 to 62 c.c.) emphasize the precarious conditions for plant growth at the latter station. Conditions at Phillipsburg were intermediate (8 to 43 c.c.).

A complete record of humidity was not obtained, but a comparison of the average daily humidity at Lincoln and Burlington at the several intervals shows that without exception the air during the day at Burlington was 10 and often 30 per cent. less humid than at Lincoln. Owing to the lower night temperatures at Burlington (altitude 4160 feet) the humidity at this less critical period averaged only slightly lower than at the true prairie station.

The average daily air temperatures are shown in Fig. 11. In general they are lowest at Burlington, while those at Phillipsburg, after the third week in 


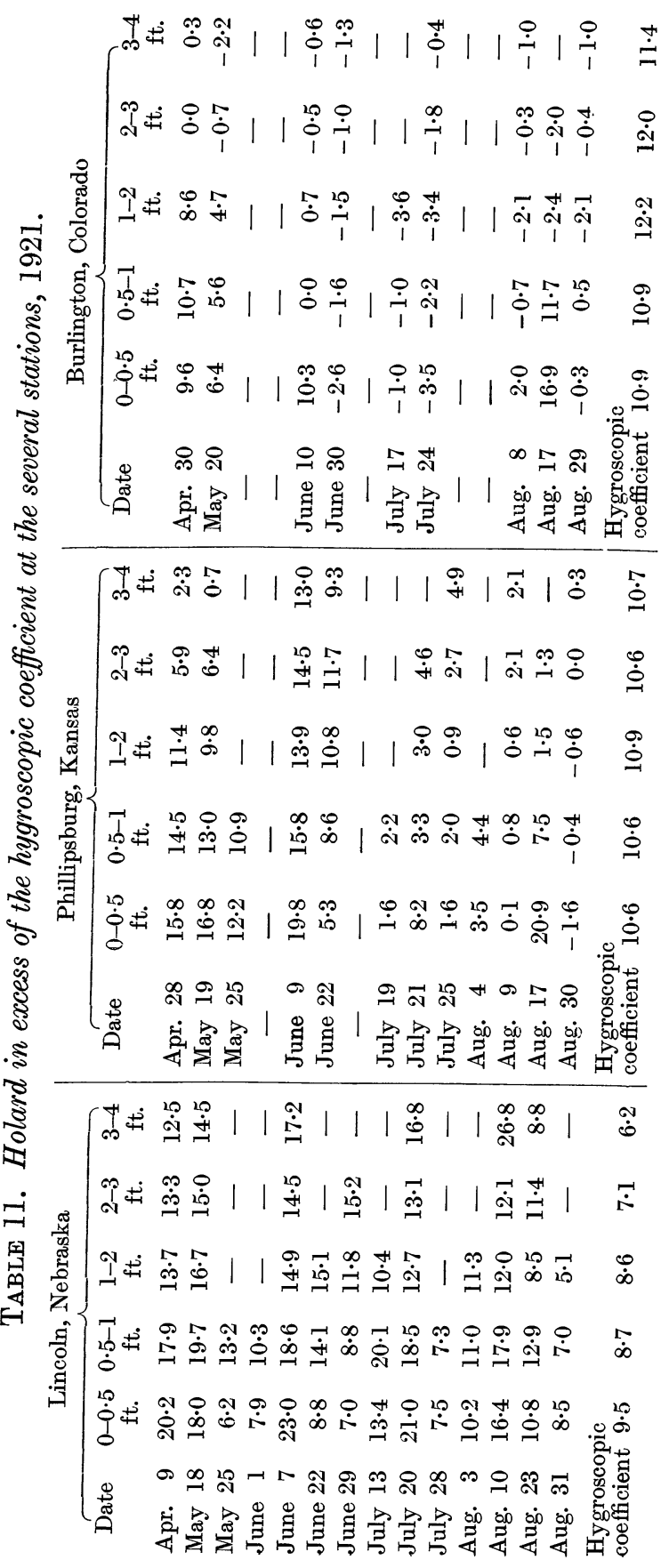




\section{Plant Production as a Measure of Environment}

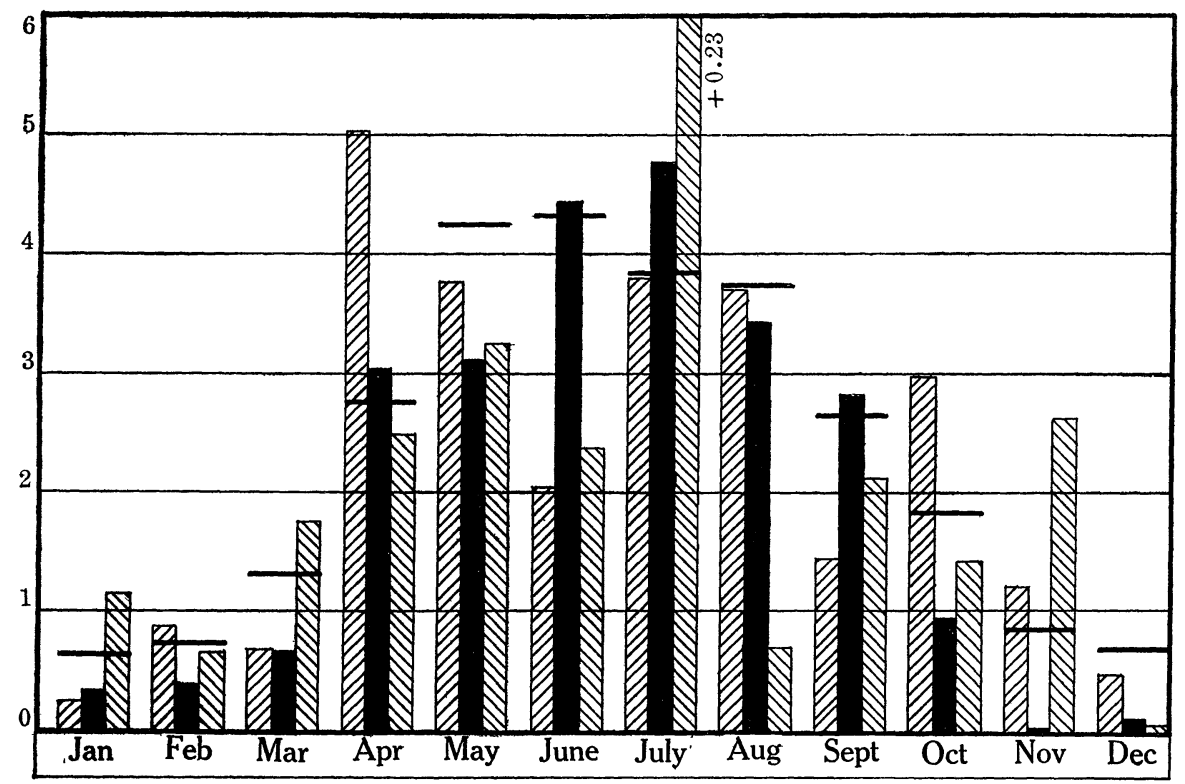

Fra. 7. Mean annual precipitation in inches (indicated by heavy short horizontal lines) and precipitation during 1920, 1921 (solid black), and 1922 at Lincoln, Nebraska.

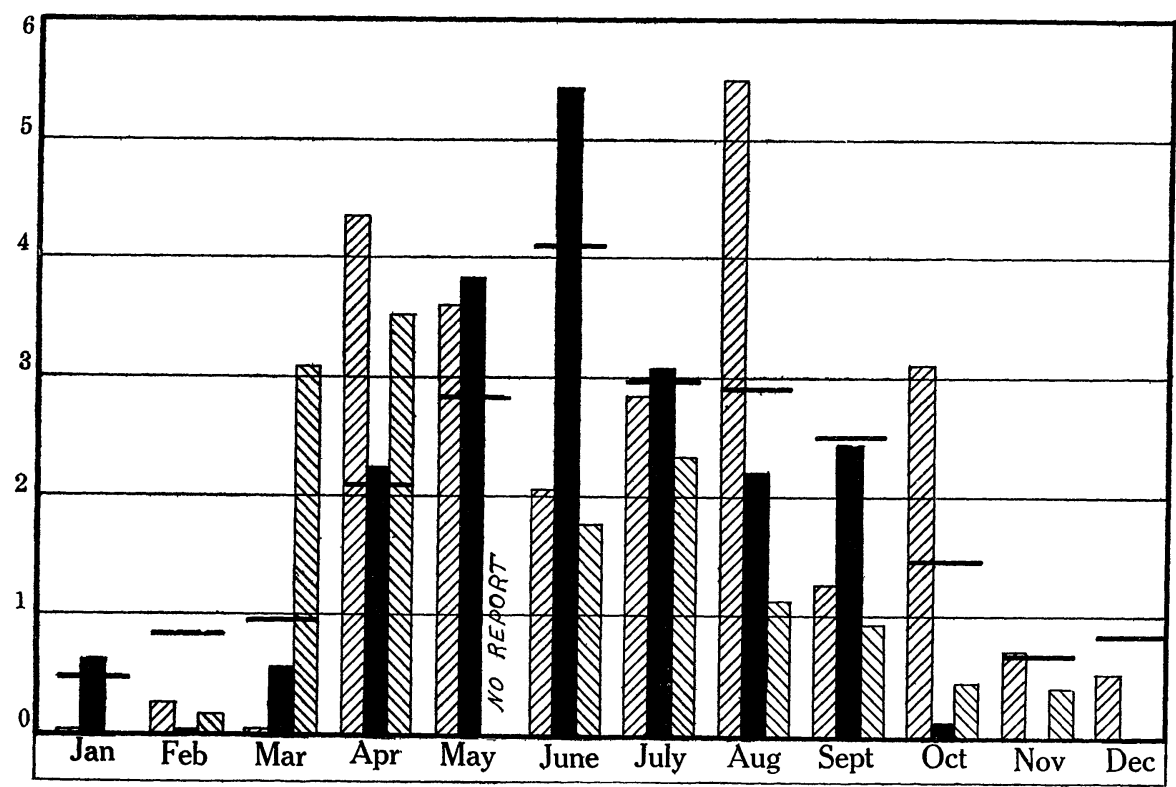

FIG. 8. Mean annual precipitation in inches (indicated by heavy short horizontal lines) and precipitation during 1920, 1921 (solid black), and 1922 at Phillipsburg, Kansas. 


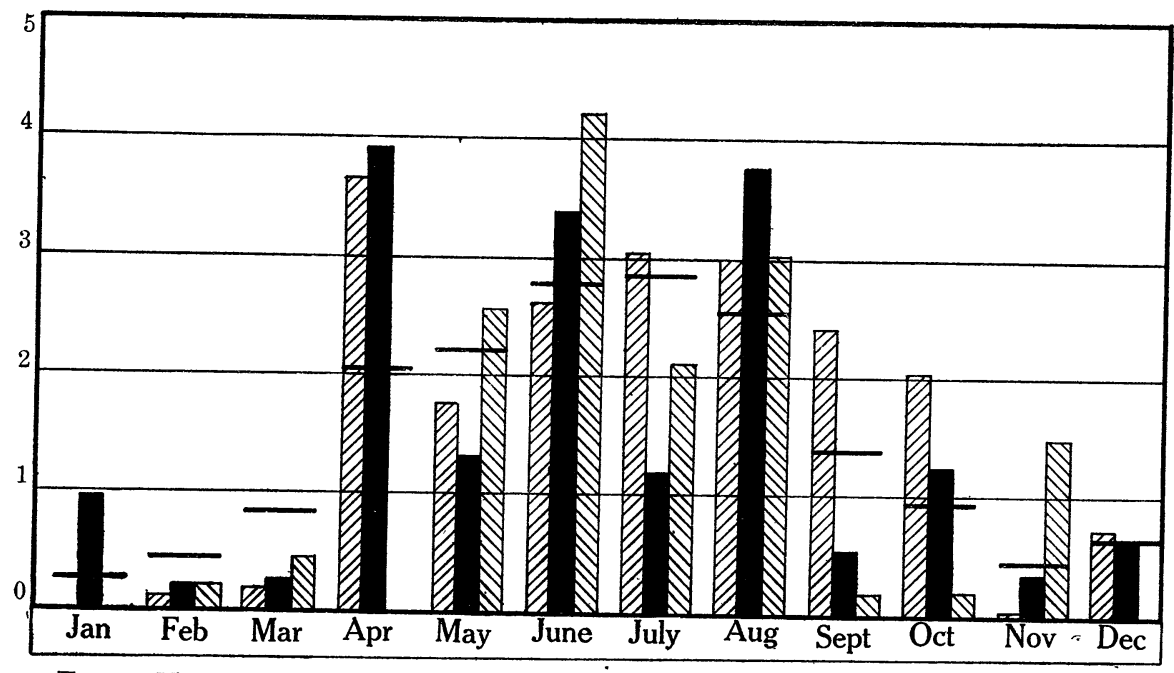

Frg. 9. Mean annual precipitation in inches (indicated by heavy short horizontal lines) and precipitation during 1920, 1921 (solid black), and 1922 at Burlington, Colorado.

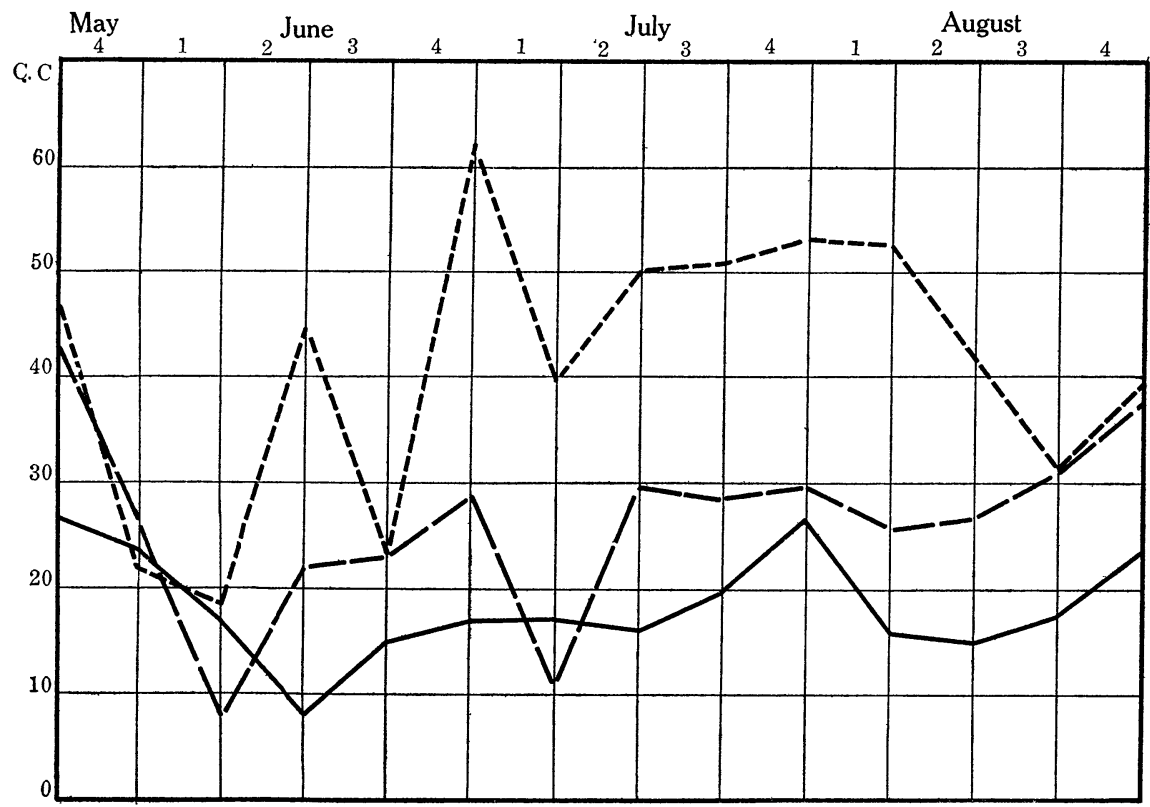

Fra. 10. Average daily evaporation at Burlington (short broken lines), Phillipsburg (long broken lines), and Lincoln (solid line), 1921. 
226 Plant Production as a Measure of Environment

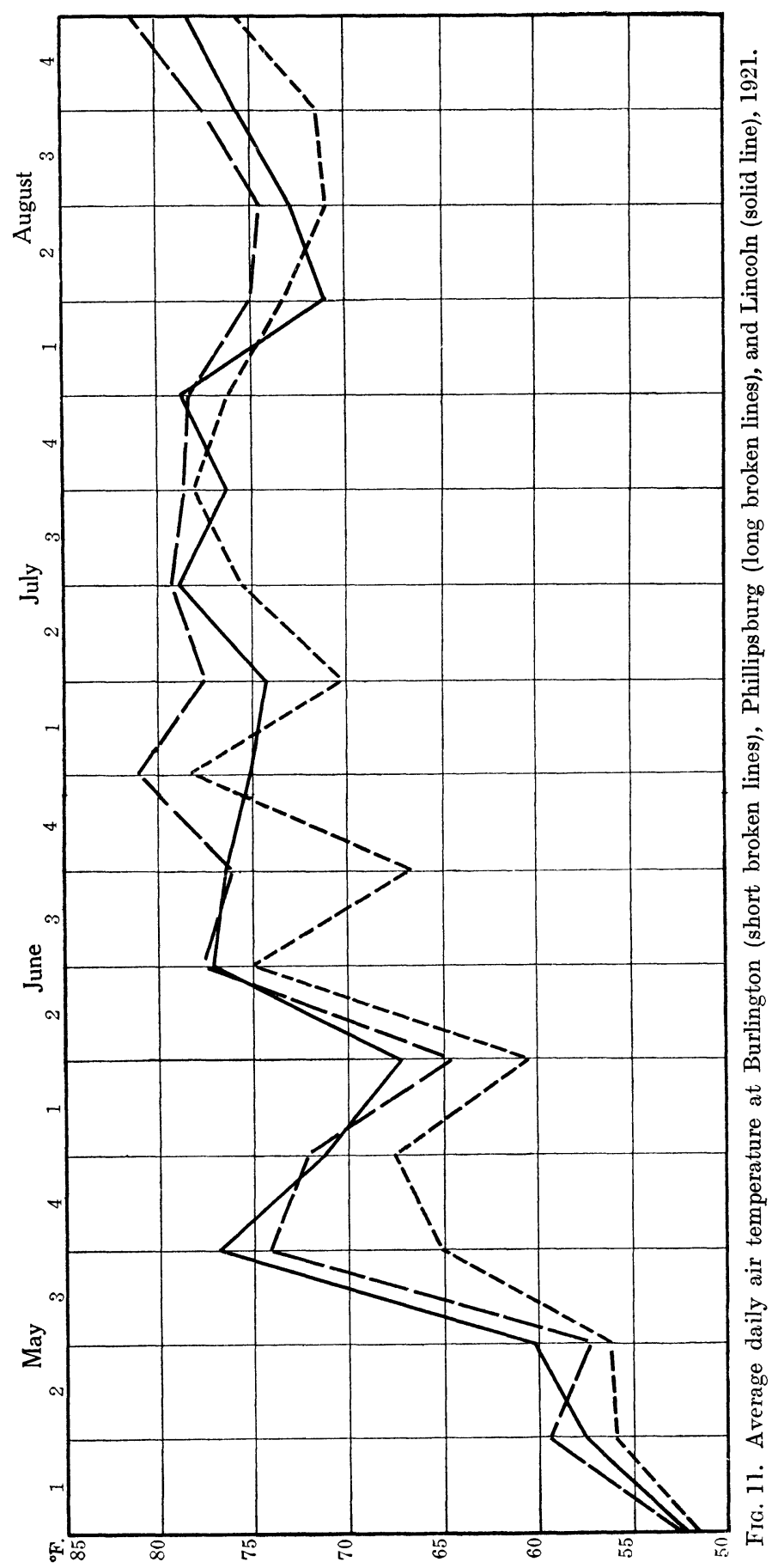


June, were somewhat higher than those at Lincoln. During May and most of June the day temperatures were highest at Lincoln and lowest at Burlington. After July 1 this condition was in most instances reversed. However, the night temperatures throughout the season were distinctly lower at Burlington by $5^{\circ}$ to $10^{\circ} \mathrm{F}$., those at the other stations being very similar.

Soil temperatures at the several stations at a depth of 3 inches until the second week in June, and at 18 inches depth thereafter are given in Fig. 12. At the shallower depth the soil at Burlington was invariably colder than that at Phillipsburg (record from Lincoln missing). Later in the season soil temperatures correlated with soil moisture, those westward from Lincoln becoming progressively drier and warmer. A series of soil temperature readings in cropped areas (oat fields) at the several stations to depths of 4 feet is of interest here (Table 12).

TABLE 12. Soil temperatures, 1921.

\begin{tabular}{|c|c|c|c|c|c|c|c|c|c|c|c|c|}
\hline \multirow[b]{2}{*}{$\begin{array}{l}\text { Depth } \\
\text { in feet }\end{array}$} & \multicolumn{3}{|c|}{ April 28-30 } & \multicolumn{3}{|c|}{ May 19-21 } & \multicolumn{3}{|c|}{ June 9-10 } & \multicolumn{2}{|c|}{ June 22} & June 30 \\
\hline & 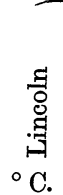 & 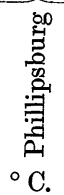 & 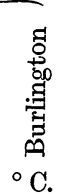 & 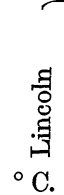 & 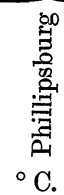 & 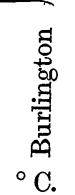 & 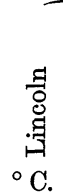 & 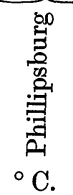 & 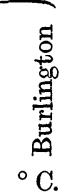 & 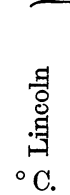 & 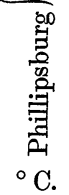 & 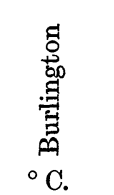 \\
\hline 0.5 & $15 \cdot 4$ & $24 \cdot 0$ & $12 \cdot 0$ & $21 \cdot 0$ & $20 \cdot 0$ & $22 \cdot 2$ & $\begin{array}{l}22.5 \\
21.5\end{array}$ & $21 \cdot 4$ & $\begin{array}{l}19 \cdot 8 \\
18.8\end{array}$ & $21 \cdot 2$ & $\begin{array}{l}23 \cdot 2 \\
2.4\end{array}$ & $29 \cdot 2$ \\
\hline $\begin{array}{r}\cdot 5-1 \\
1-2 \\
2-3\end{array}$ & $\begin{array}{l}13 \cdot 0 \\
12 \cdot 0 \\
12 \cdot 0\end{array}$ & $\begin{array}{l}23 \cdot 1 \\
15 \cdot 0 \\
14 \cdot 0\end{array}$ & $\begin{array}{l}11.0 \\
10.5 \\
10.5\end{array}$ & $\begin{array}{l}19 \cdot 0 \\
13 \cdot 4 \\
13 \cdot 1\end{array}$ & $\begin{array}{l}17 \cdot 8 \\
16 \cdot 4 \\
15 \cdot 0\end{array}$ & $\begin{array}{l}15 \\
14 \\
12\end{array}$ & $\begin{array}{l}21 \cdot 8 \\
20 \cdot 2\end{array}$ & $\begin{array}{l}20.2 \\
18.8 \\
17.2\end{array}$ & $\begin{array}{l}18 \\
16 \\
15\end{array}$ & $\begin{array}{l}21 \cdot 1 \cdot \\
20 \cdot 1 \\
18 \cdot 8\end{array}$ & $\begin{array}{l}22 \cdot 4 \\
21.5 \\
21 \cdot 2\end{array}$ & $\begin{array}{l}26 \cdot 1 \\
23 \cdot 9 \\
21 \cdot 8\end{array}$ \\
\hline $3-4$ & $10 \cdot 8$ & $\begin{array}{l}14 \cdot 0 \\
12 \cdot 0\end{array}$ & $10 \cdot 0$ & 12.0 & 13.5 & $11 \cdot \varepsilon$ & 17. & $16 \cdot 0$ & 15 & 17.4 & $20 \cdot 5$ & $20 \cdot 0$ \\
\hline
\end{tabular}

Isolated readings at similar depths showed the temperature of the grassland soil (below the first foot) to be very similar to that in the cultivated areas.

To summarize, as during 1920 conditions for plant growth were much more favourable at Lincoln and least favourable at Burlington, while those at Phillipsburg were intermediate, soil and air moisture being the controlling factors.

\section{Plant Yield.}

Two series of cuttings were made during 1921, one about July 1 and a second during the last half of August. Ten quadrats each of Bulbilis.dactyloides and Agropyrum glaucum were made at each of the stations early in the summer. At all of the stations both grasses had headed or blossomed at the time of cutting. At Burlington the buffalo grass averaged about 4.5 inches high while the staminate stalks were $5 \cdot 5$ inches long. At the mixed prairie station the foliage of this grass averaged 5 inches in height and the flower stalks 6 inches. Bulbilis occurs in the prairies at Lincoln only where the taller grasses are held in check by grazing. Hence, it was impossible to secure an ungrazed sod comparable to that at the other stations. The foliage was only 4.5 inches high and the effects of heavy overgrazing the preceding year were apparent. 
228 Plant Production as a Measure of Environment

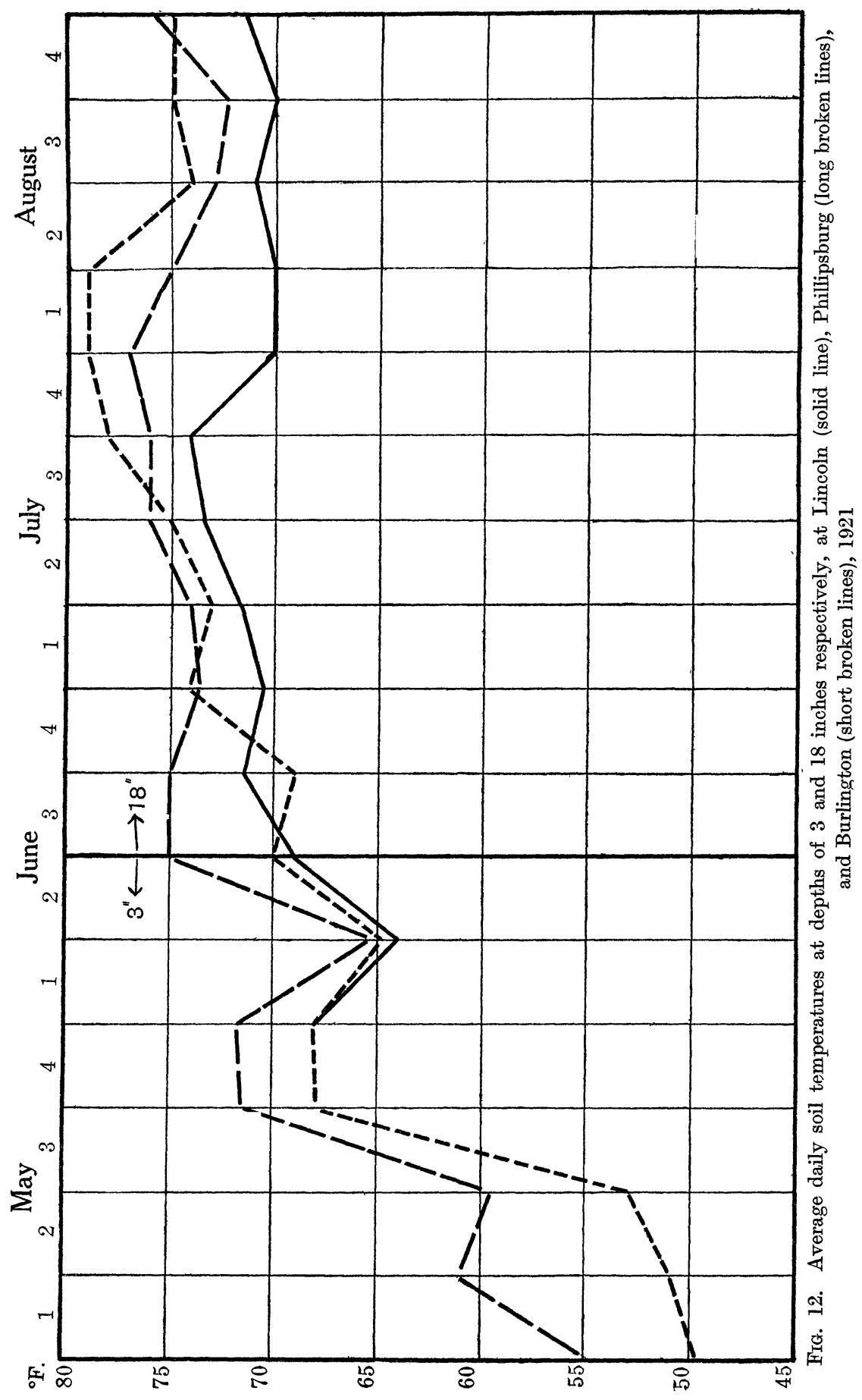


The average yield of 10 quadrats at each of the stations on July 1, proceeding eastward, was 207, 266 and 235 grams per square metre respectively.

Wheat-grass leaves at Burlington had at this time an average height of about 16 inches and the flower stalks 26 inches. At Phillipsburg these measured 22 and 30 inches respectively, while at Lincoln the foliage reached a height of 24 inches and the heads about 32 inches. The average yield of ten metre quadrats from each station was 400,457 , and 606 grams respectively.

On August 17, 12 quadrats cut in the high prairie at Lincoln yielded an average of 581 grams. A similar number from the low prairie 929 grams, giving an average yield of 755 grams. This considerably exceeded the average weight of 11 tall-grass quadrats cut on August 30 at Phillipsburg (477 grams). The average of the 44 quadrats from both cuttings at each station was as follows: Burlington 353 grams, Phillipsburg 402 grams, and Lincoln 603 grams per square metre.

Crops of the smaller cereals were again grown in 1921 under conditions similar to those already described for 1920. The yield of these crops during 1921 is shown in Table 13.

TABLE 13. Relative development of crops, 1921.

\begin{tabular}{|c|c|c|c|c|c|c|}
\hline Crop and station & $\begin{array}{c}\text { Average } \\
\text { height }\end{array}$ & $\begin{array}{l}\text { Average no. } \\
\text { stalks per } \\
\text { sq. metre }\end{array}$ & $\begin{array}{l}\text { Average } \\
\text { no. stalks } \\
\text { per plant }\end{array}$ & $\begin{array}{l}\text { Average } \\
\text { length of } \\
\text { heads or } \\
\text { panicles } \\
\text { in inches }\end{array}$ & $\begin{array}{l}\text { Average } \\
\text { no. of } \\
\text { heads per } \\
\text { sq. metre }\end{array}$ & $\begin{array}{l}\text { Average } \\
\text { total } \\
\text { weight dry } \\
\text { matter per } \\
\text { sq. metre }\end{array}$ \\
\hline Oats: & & & & & & \\
\hline $\begin{array}{l}\text { Lincoln } \\
\text { Phillipsburg } \\
\text { Burlington }\end{array}$ & $\begin{array}{l}3 \cdot 2 \mathrm{ft} . \\
2 \cdot 8 \\
1 \cdot 5\end{array}$ & $\begin{array}{l}375 \\
353 \\
414^{1}\end{array}$ & $\begin{array}{l}3 \cdot 3 \\
2 \cdot 9 \\
2 \cdot 5\end{array}$ & $\begin{array}{c}10 \cdot 5 \\
9 \\
5\end{array}$ & $\begin{array}{l}283 \\
269 \\
171\end{array}$ & $\begin{array}{l}792 \\
366 \\
180\end{array}$ \\
\hline $\begin{array}{l}\text { Wheat: } \\
\text { Lincoln } \\
\text { Phillipsburg } \\
\text { Burlington }\end{array}$ & $\begin{array}{l}3 \cdot 2 \\
2 \cdot 6 \\
1 \cdot 6\end{array}$ & $\begin{array}{l}648 \\
475 \\
419^{1}\end{array}$ & $\begin{array}{l}2 \cdot 8 \\
1 \cdot 8 \\
1 \cdot 6\end{array}$ & $\begin{array}{l}4 \\
3 \cdot 5 \\
2 \cdot 5\end{array}$ & $\begin{array}{l}365 \\
211 \\
277\end{array}$ & $\begin{array}{l}557 \\
314 \\
172\end{array}$ \\
\hline $\begin{array}{l}\text { Barley: } \\
\text { Lincoln } \\
\text { Phillipsburg } \\
\text { Burlington }\end{array}$ & $\begin{array}{l}3 \cdot 1 \\
2 \cdot 8 \\
1 \cdot 3\end{array}$ & $\begin{array}{l}384 \\
253 \\
255^{1}\end{array}$ & $\begin{array}{l}3 \cdot 7 \\
2 \cdot 2 \\
1 \cdot 6\end{array}$ & $\begin{array}{l}3 \cdot 5^{2} \\
3 \cdot 25 \\
2\end{array}$ & $\begin{array}{l}306 \\
201 \\
197\end{array}$ & $\begin{array}{l}622 \\
369 \\
122\end{array}$ \\
\hline
\end{tabular}

1 Many stalks were only 2 to 4 inches tall and had been dead for some time.

2 Average length of heads without awns.

An examination of Table 13 shows in every case, as in 1920, a decrease in height of the crop from the more humid to the more arid stations. The same general relation holds for the average number of stalks per square metre, except at Burlington, where many tiny stalks, only 2 to 4 inches tall, started growth relatively early and soon dried out, but remained until harvest. During 1920 the average number of stalks per square metre at Burlington was from one-third to one-half less than at the other stations, although the number at Phillipsburg often exceeded that at Lincoln. The average number of stalks per plant (1921) was in direct relation to the water-content of soil and other 
factors favourable or unfavourable to plant growth. In general, this relation held also during 1920. The average number of heads per square metre and the average length of heads or panicles decreased from Lincoln to Phillipsburg to Burlington respectively. An exception to this occurred in the case of the number of heads of wheat at Burlington when compared with Phillipsburg, while the difference in this respect in the case of barley was small. However, a clear gradation in the reduction of total dry weight from east to west is apparent, giving a direct correlation with differences in water-content of air and soil.

\section{EXPERIMENTS DURING 1922.}

\section{Environmental Conditions.}

The season of 1922 at Lincoln was much less favourable as regards precipitation than that of 1921. Rainfall during April, May, and especially June was far below the normal (Fig. 7). July gave an excess of nearly $2 \cdot 5$ inches but a severe drought occurred during August when only 0.7 of the normal $3 \cdot 7$ inches of precipitation fell. The vegetation showed by partial wilting and early browning the lack of sufficient water for normal development.

At the mixed prairie station drought conditions prevailed as early as June which month had $2 \cdot 4$ inches less than the normal rainfall (Fig. 8). The July precipitation was also below normal as well as that of August. The precipitation at Burlington was above normal during May, considerably above during June and August but somewhat below during the July drought. However, frequent periods of 7 to 14 or more days duration occurred when no available water fell.

Soil moisture conditions are shown in Table 14. Notwithstanding the late summer drought a margin of at least 5 per cent. available water was found at all depths to which samples were taken at Lincoln (except on June 22 and August 17 and 24) while 10 per cent. or more was usual at the low prairie station. In the mixed prairie a period when little or no water was available occurred in June, and this condition was rather constant from the middle of July until fall. Data from Burlington show, as usual, rather continuous drought conditions after the middle of June, broken only occasionally by available water in the surface soil.

The evaporating power of the air at the several stations is shown in Fig. 13. The more xerophytic conditions on the great plains as contrasted with the more humid air of the true prairie are again pronounced. At all stations the rates were high in June and again in August. In general, evaporation was greater at Lincoln than during 1921 (Fig. 10) but considerably less at Burlington.

A comparison of the humidity records shows, as during previous seasons, that the air was much drier (often 10-30 per cent.) at Burlington during the day than at Lincoln, and also usually somewhat less humid at night. 


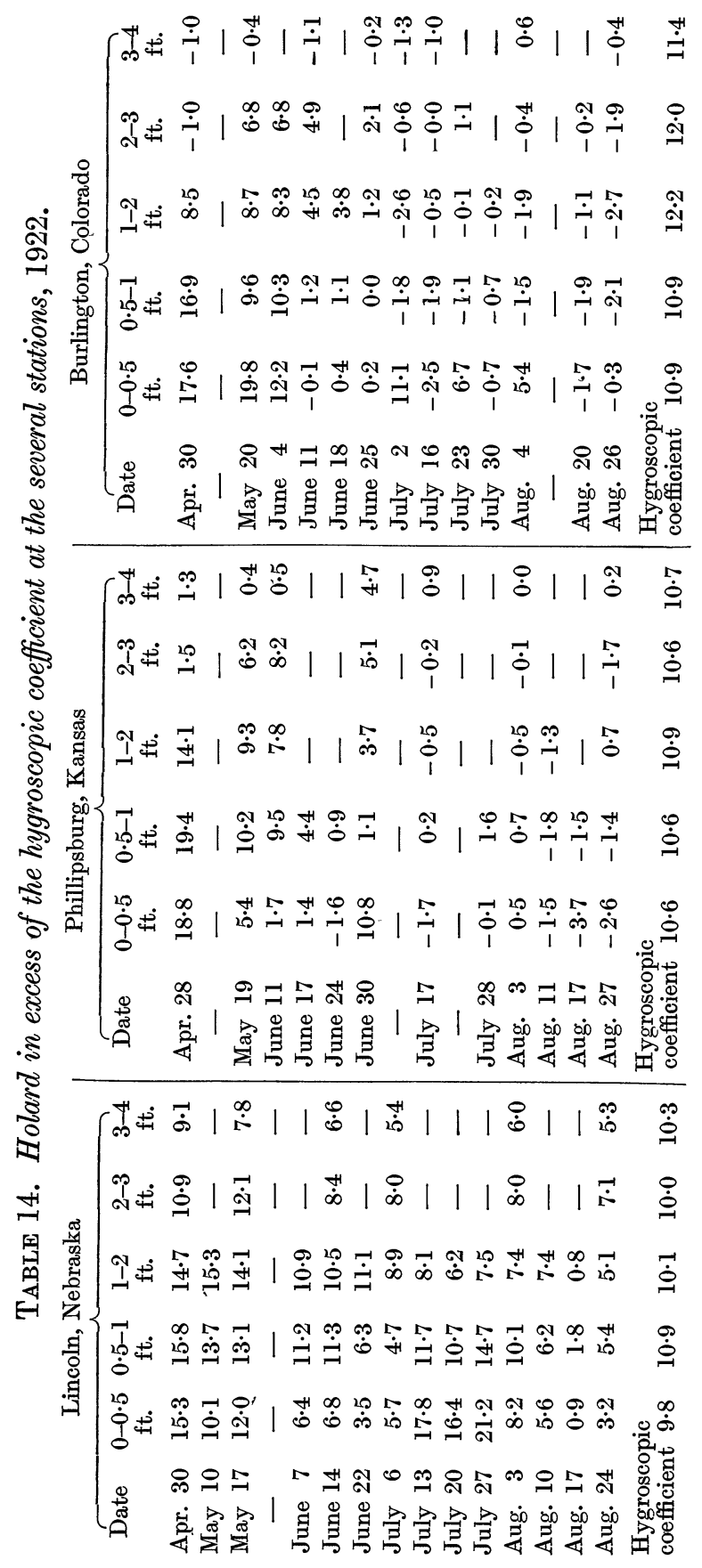




\section{2}

\section{Plant Production as a Measure of Environment}

The average day and average night temperatures at the several stations are shown in Fig. 14. An outstanding feature of these graphs is the rather consistently lower night temperatures at Burlington, although the air in the mixed prairie was usually warmer than that at Lincoln. Marked differences in day temperatures are not apparent at the several stations, except during August, when the temperatures at Burlington were markedly lower than at either of the other stations. Soil temperatures are so similar to those of preceding years that these data need not be given. It seems clear however that such small differences in temperature would have little effect upon the growth of the native vegetation, water content being the controlling factor.

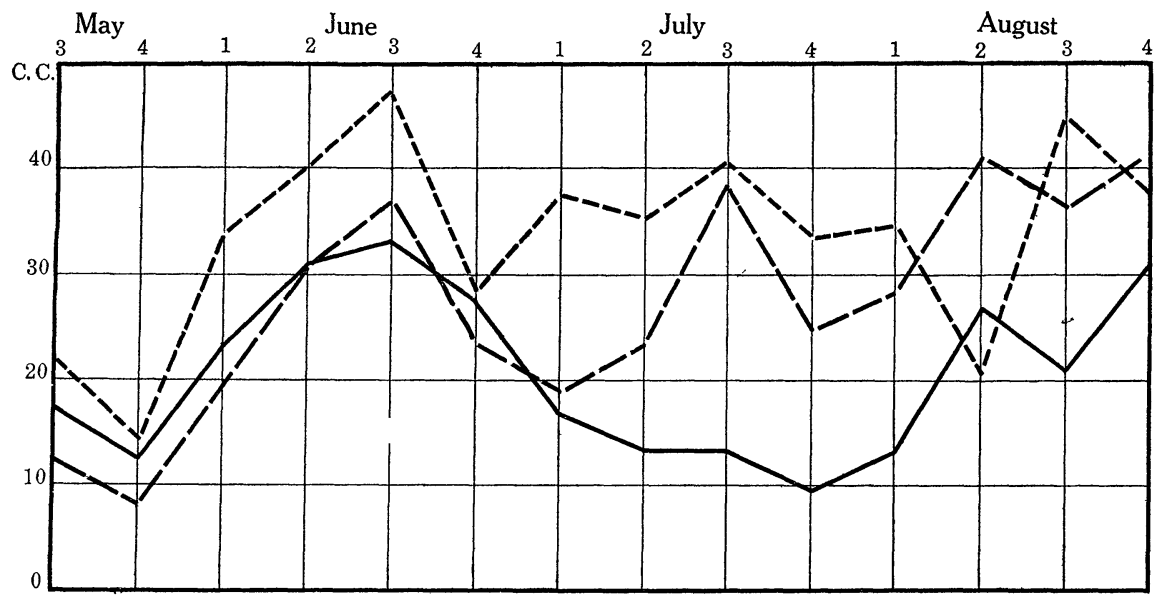

Fic. 13. Average daily evaporation at Burlington (short broken lines), Phillipsburg (long broken lines), and Lincoln (solid line), 1922.

As during preceding years, soil and air moisture conditions were most favourable in the true prairie, intermediate in mixed prairie and poorest of all on the short-grass plains.

\section{Native Plant Yield.}

Only one series of cut quadrats was obtained in 1922. This was taken on August 4 to 15 beginning at the short-grass plains station. A series of seven quadrats of Bulbilis at Burlington yielded an average of 179 grams, while the average of a similar series at Phillipsburg was 260 grams. A series of mixed short- and tall-grass cuttings at these two stations yielded 263 and 365 grams respectively. Differences in height-growth of foliage and flower stalks of both kinds of grasses were again similar to those already recorded.

A series of eight representative quadrats of wheat-grass at both Phillipsburg and Lincoln was also obtained. The average heights of the foliage and flower stalks respectively were 15 and 26 inches at the former station and 17 and 30 inches at the latter. The yield in the same sequence was 334 and 541 grams per square metre. 


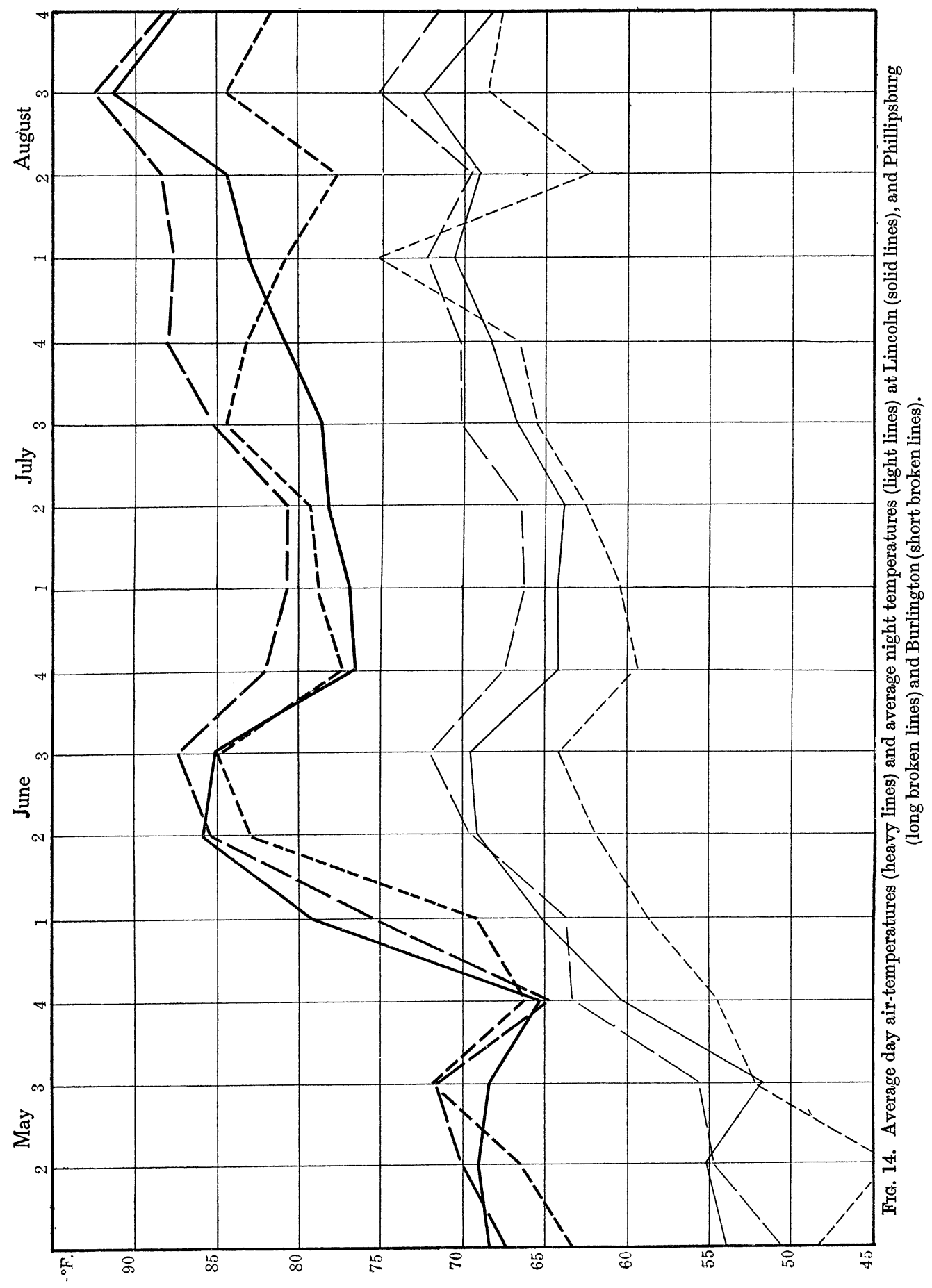


A series of 27 quadrats consisting of mixed tall-grasses (largely of Andropogon scoparius, $A$. furcatus and $A$. nutans) was secured from these two stations. Repeated measurements showed that the average height of the general level of the foliage.was 3 to 8 inches greater at Lincoln (13 to 24 inches tall) than in the mixed prairie. The yield in grams per square metre was 287 and 413 at the two stations, Lincoln ranking first.

The average yield of all of the quadrats for this year in the three grassland communities was 224, 311 and 442 grams at Burlington, Phillipsburg and Lincoln respectively.

Growth of MaIze. 1922.

Five fields of maize were selected as representative of conditions about each of the three stations respectively. All of these were within a radius of two miles of the stations at which soil moisture and other factor determinations were made. In all the fields the corn had been drilled in rows 3.5 feet apart. The average number of stalks in rows 100 feet long as well as the number of stalks bearing ears was determined at five or more places in each field. Ten stalks were then selected from various places in the field and the measurements recorded in Table 15 were made. The seventh leaf was selected for measurements of length and width. These measurements were all made from August 27 to September 2. Dry weather had caused the crop to ripen somewhat prematurely and considerably reduced the yield. In practically all the fields the husks were drying and the kernels were well dented. The leaves were from one-half to two-thirds dried, the lower ones especially being driest. After completing the measurements on each stalk, the ear was husked and placed in a sack, ten ears being secured from each field. Finally a typical stalk, as determined by the measurements of the ten preceding, was selected, cut off at the ground line, cut into pieces and after removing the ear but not the husks was placed in another sack. These sacks were kept well ventilated and after all had become thoroughly air dried in a laboratory at the University of Nebraska the weight of their contents was ascertained.

An examination of Table 15 shows that the number of stalks in a row as well as the number of ears was greatest at Lincoln. Obviously the rate of planting at Burlington, which was only 10 per cent. less than at Lincoln, was too high for greatest production, competition for water being excessive, as is indicated by the low stature and yield of the crop. Better growth occurred at Phillipsburg, due undoubtedly in part to the lower rate of planting. Consistent and marked increases in height and diameter of stalk, height of ear, number and length of leaves, length and diameter of ear as well as dry weight of stalks and ears were found proceeding from west to east. However, little difference occurred in leaf width. These data are summarized in Table 16 where the several measurements at Lincoln are used to represent 100 per cent. 


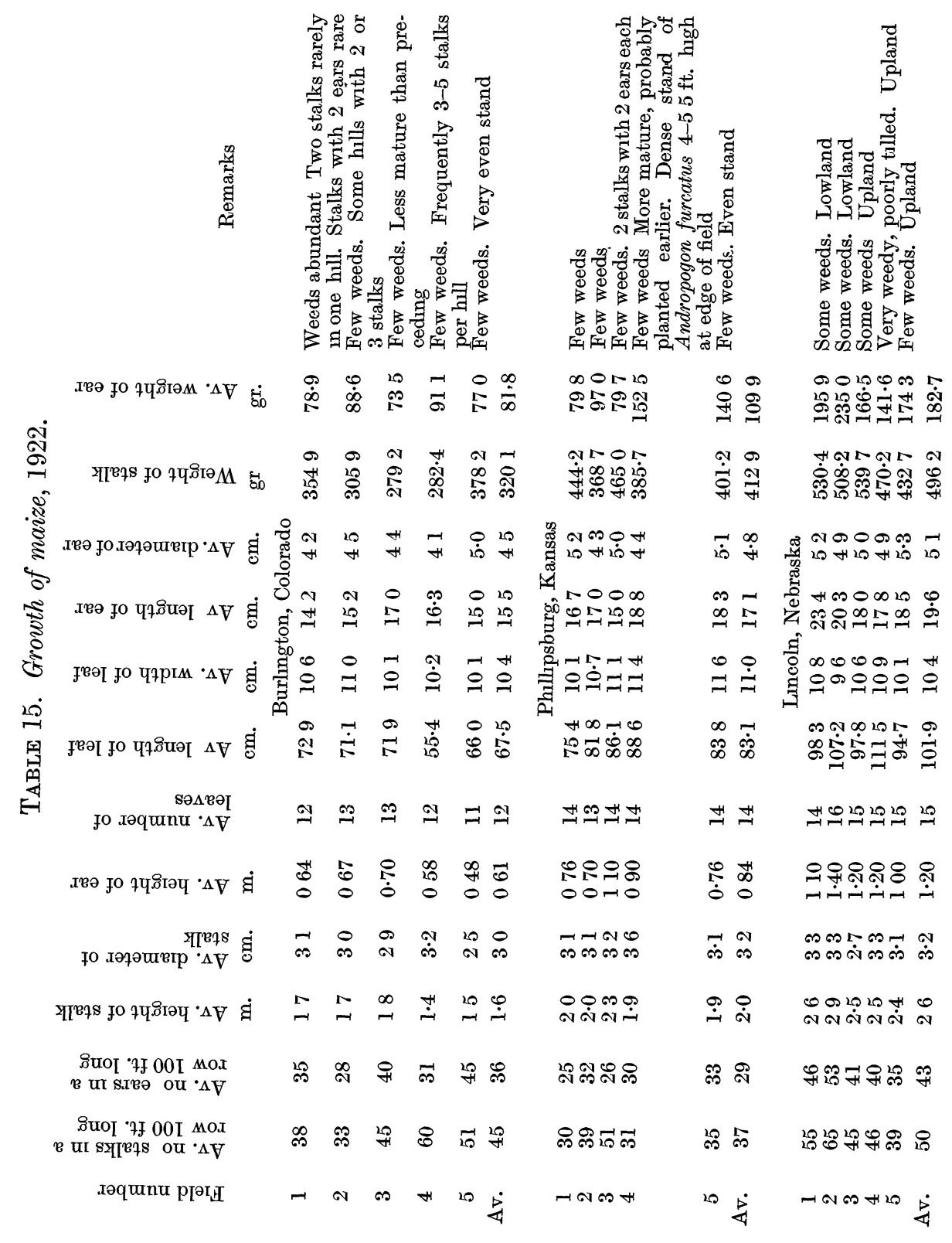


TABLE 16. Growth of maize during 1922.

$\begin{array}{lccc} & \text { Lincoln } & \text { Phillipsburg } & \text { Burlington } \\ \text { Height of stalk } & 100 & 77 & 62 \\ \text { Diameter of stalk } & 100 & 100 & 94 \\ \text { Height of ear } & 100 & 70 & 51 \\ \text { Number of leaves } & 100 & 93 & 80 \\ \text { Length of leaves } & 100 & 82 & 66 \\ \text { Width of leaves } & 100 & 106 & 100 \\ \text { Length of ear } & 100 & 87 & 79 \\ \text { Diameter of ear } & 100 & 94 & 88 \\ \text { Dry wt. of stalk } & 100 & 83 & 64 \\ \text { Dry wt. of ear } & 100 & 60 & 45\end{array}$

From these data it may be seen that the maize plant integrates environmental differences as measured by instruments in quite the same way as cereals, legumes, or native vegetation.

\section{SUMMARY OF EXPERIMENTS ON NATIVE VEGETATION.}

A summary of the experiments with native vegetation is given in Table 17. From these data, extending over a period of three years, some interesting conclusions may be drawn.

TABLE 17. Average weight of cut quadrats in grams, 1920, 1921 and 1922.

\begin{tabular}{|c|c|c|c|c|c|c|c|c|}
\hline minant type of vegetation & 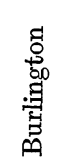 & 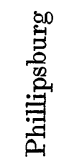 & $\begin{array}{l}\text { : } \\
\text { 节 }\end{array}$ & 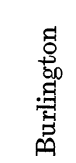 & 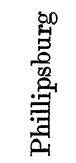 & 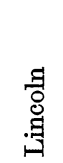 & 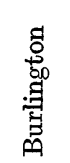 & 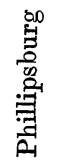 \\
\hline Buffalo grass & 98 & 290 & - & 207 & 266 & 235 & 179 & 260 \\
\hline & 50 & & - & 00 & 457 & 60 & & \\
\hline Mixed short- and tall-grasses & 197 & & $\overline{-0}$ & - & & $\overline{-\sigma}$ & 263 & \\
\hline Mixed tall-grasses & - & 410 & 458 & - & 477 & 755 & - & 287 \\
\hline $\begin{array}{c}\text { Average (based on number of } \\
\text { quadrats) }\end{array}$ & 183 & 378 & 458 & 353 & 402 & 603 & 224 & 11 \\
\hline
\end{tabular}

In every case a certain grass or mixture of grasses yielded progressively more as the water-content of the soil increased, i.e. proceeding from the western stations eastward. The only exception is the case of buffalo grass at Lincoln in 1921, and this has already been explained as an effect of grazing. Moreover, the averages for each year at the several stations show a graduated series, plant production increasing with increased efficient rainfall. However, it may be readily seen that the total yield at all of the stations was greater in 1921 than during the preceding or following year. The increases of 1921 over 1920 are particularly noticeable in the development of the late maturing tall-grasses. The yield in 1922 was less in every case than in 1921. A comparison of the available soil moisture gives the explanation for the cause of the differences.

\section{SUMMARY.}

During the past three years an attempt has been made to determine the precise relation between habitat factors as measured by instruments and plant response as determined by growth. Stations were chosen at Lincoln, Nebraska, as representative of conditions in the true prairie (Stipa-Koeleria) 
association, at Phillipsburg, in north-central Kansas in the mixed prairie (Stipa-Bouteloua) association and at Burlington in eastern Colorado in the short-grass plains (Bulbilis-Bouteloua) association.

At each station all of the important aerial and edaphic ecological factors such as rainfall, water and nutrient content of soil, humidity, evaporating power of the air, soil and air temperature, and wind movement were measured and compared during three growing seasons. Plant production of native grasses and the smaller cereal crops was determined by means of the employment of a large number of cut metre quadrats. The relative production of certain legumes and maize was also ascertained.

It was early determined that the water relations of soil and air were controlling, other factors being merely contributory. The yield of pure stands of short-grasses (Bulbilis dactyloides and Bouteloua gracilis), wheat-grass (Agropyrum glaucum), mixed short- and tall-grasses, and mixed tall-grasses was found to decrease from the true prairie through mixed prairie to shortgrass plains directly in proportion to available water-content of soil and inversely proportional to the evaporating power of the air. The same relation was determined not only for the smaller cereals (oats, wheat and barley) but also for alfalfa and sweet clover as well as for maize. The plant yield at each station during different seasons also correlated well with the variations in the water relations. Since deficiencies in water-content were most marked late in the summer, the differences in plant production were often greatest in late maturing tall-grasses at the eastern stations. Thus native and crop plants are shown to integrate environmental conditions and to express them quantitatively in yield.

\section{BIBLIOGRAPHY.}

Briggs, L. J. and Shantz, H. L. (1912). "The wilting coefficient for different plants and its indirect determination." U.S. Dept. Agr., Bur. Pl. Ind. Bull. 230.

Glements, F. E. (1920). "Plant Indicators." Carnegie Inst. Wash. Pub. 290.

Glements, F. E. and Weaver, J. E. (1922). "Transplant quadrats and areas." Carnegie Inst. Wash. Year Book 21, 346.

Shantz, H. L. (1911). "Natural vegetation as an indicator of the capabilities of land for crop production in the Great Plains area." U.S. Dept. Agr., Bur. Pl. Ind. Bull. 201.

Weaver, J. E. and Thiel, A. F. (1917)."Ecological studies in the tension zone between prairie and woodland." Rep. Bot. Surv. Nebr. n.s. 1, 1.

Weaver, J. E. (1919). "The ecological relations of roots." Carnegie Inst. Wash. Pub. 286.

Weaver, J. E. (1920). "Root development in the grassland formation." Carnegie Inst. Wash. Pub. 292.

Weaver, J. E. and Grist, John W. (1922). "Relation of hardpan to root penetration in the Great Plains." This Journal, 3, 237.

Weaver, J. E., Jean, F. G. and Grist, John, W. (1922). "Activities and development of the roots of crop plants." Carnegie Inst. Wash. Pub. 316. 